\title{
Economic disasters and aggregate investment
}

\author{
Bruno Ćorićc ${ }^{1,2}$ (1) Vladimir Šimić V $^{1,2}$
}

Received: 9 December 2019 / Accepted: 28 December 2020 / Published online: 20 January 2021

(C) The Author(s), under exclusive licence to Springer-Verlag GmbH, DE part of Springer Nature 2021

\begin{abstract}
The 2007-2008 global financial crisis has spurred an increasing interest for investigating the financial and macroeconomic effects of the rare but extremely large economic crises, the so-called economic disasters. Current literature on the topic shows that probability of economic disasters plays an important role in the long-run effect of output volatility on investment. This paper investigates the long-run relationship between economic disasters and aggregate investment. We analyze the data for a large number of developing and developed countries after the World War II. The conducted panel data analysis indicates a negative effect of the probability of economic disasters on aggregate investment. Our results contribute to the recent literature on economic disasters by providing empirical support for the hypothesis that probability of infrequent but extremely large economic crises has a negative longrun effect on investment. We also find that the effect of 'normal' output volatility on aggregate investment is relatively small.
\end{abstract}

Keywords Aggregate investment - Economic disasters · Output volatility · Empirical analysis

JEL Classification E22 - E32

\section{Introduction}

The crush of the subprime mortgages market in 2007 resulted in one of the most severe financial crises in the US history. By 2008, the crisis had spread across the world causing the first global economic downturn after the World War II (WWII). The negative impact of the financial crisis appears to be lasting a lot longer than in

Bruno Ćorić

bcoric@efst.hr

Vladimir Šimić

vsimic@efst.hr

1 Faculty of Economics, University of Split, Cvite Fiskovića 5, 21000 Split, Croatia

2 CERGE-EI Foundation, 110 Jabez Street \#1004, Newark, NJ 07105, USA 
a usual cyclical recovery, especially in advanced economies. The crisis has led to a "new normality" or "secular stagnation", referring to a very sluggish output growth, persistently binding zero lower bound on the short-term nominal interest rate and inflation below target (Candelon et al. 2016, 2020; Eggertsson et al. 2019).

Since this crisis researchers have become increasingly interested in the financial and macroeconomic effects of the rare but extremely large economic crises, the socalled economic disasters. The term economic disaster is introduced in the literature by Barro (2006) to denote especially large economic crises. These crises could reflect economic and non-economic events such as the Great Depression, financial crises, sovereign defaults, revolutions, wartime destructions, natural disasters and epidemics of disease such as Black Death, avian flu or the current COVID-19 pandemic. Economic disasters are formally defined by Barro and Ursúa (2008, 2012) as a short-run cumulative decline in output of a magnitude greater than 10 percent. The recent theoretical research suggests that probability of these rare but extremely large economic crises has good explanatory power for an array of asset-pricing puzzles (see, for example, Barro 2006; Barro and Ursúa 2012; Gabaix 2012; Gourio 2013; Wachter 2013; Tsai and Wachter 2015; Barro and Liao 2016; Barro and Jin 2018; Seo and Wachter 2019). The growing literature also considers the impact of economic disasters on business cycles, debt intolerance of developing economies, exchange rate, investment, long-run output growth and welfare (see for example: Barro 2009, Gourio 2012, Pindyck and Wang 2013, Isore and Szczerbowicz 2017; Farhi and Gabaix 2016; Rebelo et al. 2018).

This paper contributes to this literature by focusing on the relationship between aggregate investment and economic disasters. In particular, Barro (2009) suggests that economic disasters can have an important role in the effect of output volatility on investment. He constructed an AK model of output growth according to which probability of infrequent but large economic disasters reduces the risk-adjusted return on capital and hence reduces investment and output growth.

We seek to empirically identify and estimate this hypothesized long-run effect of economic disasters on aggregate investment. Due to the limited historical data on aggregate investment, our analysis focuses on the post-WWII period. As argued by Barro (2006), economic disasters are relatively rare events. Thus, identification of a sufficient number of country-specific economic disasters requires long time series. Accordingly, most studies on economic disasters employ country level data on economic disasters obtained from the Barro and Ursúa's (2008, 2012) historical database for 42 OECD and non-OECD countries. However, Ćorić (2020) recently employed the original Barro and Ursúa's (2008, 2012) methodology to identify country-specific economic disasters in a much broader set of countries. This new dataset identifies 237 economic disasters across 212 countries from 1950 to 2014, providing us with a sufficient number of these events (economic disasters) for a meaningful empirical analysis.

So, to estimate the relationship between economic disasters and aggregate investment, we construct a large dataset covering above one hundred developing and developed countries from 1960 to 2017 and employ the recent Ćorić's (2020) country level data on economic disasters after the WWII. The relationship is estimated within the standard neoclassical model of investment by using the Blundell 
and Bond (1998) system GMM and Lewbel's (2012) estimator. The results of our panel regression analysis provide empirical support to the Barro's (2009) hypothesis. In particular, we uncover a significantly negative long-run effect of economic disasters on aggregate investment. The estimated negative effect appears to be robust with respect to the introduction of a number of standard control variables and to the corresponding variations in the sample size, alternative estimation methods and an alternative construction of the data sample. Consistently with the results of the Barro's (2009) theoretical model, we also find that the effect of 'normal' output volatility on aggregate investment is relatively small.

The paper is organized as follows. Section 2 provides theoretical background for our research. Section 3 describes the used model and data construction. Section 4 presents the results of the empirical analysis. Section 5 concludes.

\section{Theoretical background}

Lucas (1987) challenged the conventional wisdom by suggesting that the calculation of the welfare losses over the post-WWII period in the United States reveals very small welfare costs of business cycles. Lucas' seminal research gave impetus to a large literature on the welfare effects of business cycles. A number of researchers have been arguing that Lucas' calculation failed to take into account an important cost of output volatility caused by the negative effect of output volatility on longrun output growth (see for example, Obstfeld 1994; Epaulard and Pommerte 2003; Krebs 2003; Jones et al. 2005; Wang and Wen 2011). ${ }^{1}$

As argued in Barlevy (2004), the most commonly cited reason as to why output volatility might affect growth negatively concerns the possible negative effect of output volatility on investment due to an increase in uncertainty. In particular, the negative effect of output volatility on growth is consistent with the AK class of economic growth models if the uncertainty caused by output volatility discourages investment more than it encourages precautionary saving (Stadler 1990; King and Rebelo 1993; Obstfeld 1994). However, Jones et al. (2005) show that this requires the size of the coefficient of the relative risk aversion to lie outside the standard range (see the details below).

The empirical support for the negative long-run effect of output volatility on aggregate investment is also limited. In particular, the influential empirical research by Ramey and Ramey (1995) suggests that the countries with higher output volatility have on average lower output growth. The negative effect of output volatility on long-run growth has been reported in the number of ensuing empirical researches (see for example Martin and Rogers 2000; Fatas 2002; Rafferty 2005; Kose et al. 2006; Badinger 2010). Nevertheless, Ramey and Ramey (1995) found little evidence that aggregate investment played an important role in this relationship. Their results show that the relationship between output growth and volatility is unchanged by the addition of investment as a control variable. The results also reveal little impact

\footnotetext{
1 See Priesmeier and Stahler (2011) for the review of this literature.
} 
of output volatility on investment. Some empirical evidence on the negative relationship between volatility and investment was provided in Aizenman and Marion (1999). Still, this negative effect was limited to the effect of volatility on private investment in developing countries. ${ }^{2}$

The recent literature on economic disasters underlines the possible role of economic disasters in the relationship between output volatility and aggregate investment. In particular, Rietz (1988) suggested that the so-called equity premium puzzle $^{3}$ can be explained by introducing economic disasters into the asset-pricing model. The insight was that the return on shares is excessively high compared to the return on riskless assets (government bonds) to compensate investors for the risk of low-probability events with large negative economic effects. Since Barro (2006) resurrected the original Rietz's (1988) idea that economic disasters might be a major determinant of the asset risk premia, the rare disaster models have been used in modeling many financial phenomena such as the low risk-free rate (Gabaix 2012), the predictability of excess equity returns (Watcher 2013), the corporate bond spreads that are higher than the expected credit losses (Gabaix 2012 and Gourio 2013), the volatility of equity returns (Barro and Jin 2018), the option prices (Barro and Liao 2016; Seo and Wachter 2019). This approach has also been used to analyze the characteristics of business cycles (Gourio 2012 and Isore and Szczerbowicz 2017), the debt intolerance of emerging economies (Rebelo et al. 2018), the excess volatility of exchange rates and the failure of the uncovered interest rate parity (Farhi and Gabaix 2016). ${ }^{4}$

In a recent research, Barro (2009) uses the economic disasters framework to address the issue of the low welfare costs of business cycles. Building on the standard AK growth model he shows that probability of economic disasters can have an important role in the long-run effect of output volatility on investment, output growth and hence welfare. More precisely, in the standard AK class of growth models in which the representative agent maximizes the expected lifetime utility by maximizing the intertemporal consumption function, the effect of uncertainty related to output volatility on investment and hence output growth depends on whether the agent's intertemporal elasticity of substitution for consumption (IES) is greater or less than unity. If the IES $>1$, output volatility reduces investment (and output growth). In this case, the dominant effect of uncertainty related to output volatility is to reduce the risk-adjusted return on capital and therefore

\footnotetext{
${ }^{2}$ Note that the potential short-run effect of uncertainty on investment has been studied extensively. A large body of literature focuses on 'real options' (Bernanke 1983; Pindyck 1991; Bloom 2009), that is, on the idea that under irreversibility of investment firms that face an increase in uncertainty may prefer to wait and delay their investment until uncertainty is resolved. The short list of the recent researches in this literature include: Bloom et al. (2007), Panousi and Papanikolaou (2012), Bachmann et al. (2013), Glover and Levine (2015), Buchholz et al. (2016) and Meinen and Roehe (2017). For a detailed overview of the literature on uncertainty and the relationship between uncertainty and investment see Carruth et al. (2000) and Bloom (2014).

3 The equity premium puzzle refers to the finding that the standard consumption-based asset-pricing models cannot explain the amount of the excess real return on stocks relative to the return on government bills assuming reasonable levels of risk aversion (Mehra and Prescott 1985).

4 See Tsai and Wachter (2015) for a survey of the economic disasters models.
} 
reduce savings and hence investment. On the other hand, if the IES $<1$, then output volatility increases investment because the dominant effect of uncertainty in this case is to increase precautionary savings and investment. In the standardly used additive-utility function, the IES is constrained to equal the reciprocal of the coefficient of the relative risk aversion $($ IES $=1 / \gamma)$. This purely mechanical restriction implies that the negative effect of output volatility on investment requires $\gamma<1$. Although empirical estimates of $\gamma$ vary broadly Gandelman and Hernandez-Murillo (2015) suggest that the most widely accepted values of $\gamma$ lie between 1 and 3 . These values of $\gamma$ imply a positive effect of output volatility on investment. Barro (2009) relaxes this restriction by adopting the recursive utility function of Epstein and Zin (1989) and Weil (1990) that disentangles the coefficient of relative risk aversion, $\gamma$, from the intertemporal elasticity of substitution (IES). He shows that for the standard values of values of $\gamma$ and IES $(\gamma>1$ and IES $>1$ ) the AK growth model with this formulation of utility function implies a negative effect of uncertainty related to output volatility on investment. However, he also shows that, for the conventional values of $\gamma$ and IES, the effect of uncertainty related to 'normal' output volatility is quantitatively small and that the main adverse effect on investment comes from the uncertainty related to the probability of infrequent but very large economic disasters.

\section{Empirical model and data description}

\subsection{Setting up the model}

To test the hypothesized relationship between probability of economic disasters and aggregate investment, we employ a simple specification of the standard neoclassical model (Hall and Jorgenson 1967).

$$
K_{i, t}^{*}=\frac{\alpha Y_{i, t}}{R_{i, t}^{\sigma}}
$$

where $K_{i, t}^{*}$ is an optimal capital stock in country $i$ at period $t . Y_{i, t}$ is output, $R_{i, t}$ is cost of capital, while $\alpha$ and $\sigma$ denote, respectively, the output and substitution elasticities of capital. The empirically estimable investment specification is obtained by substituting the optimal capital stock with the capital accumulation equation,

$$
K_{i, t+1}=(1-\delta) K_{i, t}+I_{i, t}
$$

in which $I_{i, t}$ denotes investment and $\delta$ is depreciation rate of capital.

In particular, in the steady state, the growth rate of capital is equal to the growth rate of output, $\mu$, hence,

$$
K_{i, t+1}=\left(1+\mu_{i, t}\right) K_{i, t}
$$

By introducing Eq. (1) and (2) into (3), we obtain the following investment equation, 


$$
I_{i, t}=\left(\mu_{i, t}+\delta\right) \frac{\alpha Y_{i, t}}{R_{i, t}^{\sigma}}
$$

that after rearranging and taking logarithm of (4) yields a simple empirically estimable linear investment equation.

$$
i_{i, t}=\beta+g_{i, t}-\sigma r_{i, t}
$$

In which $i_{i, t}=\ln \frac{I_{i, t}}{Y_{i, t}}, \beta=\ln \alpha, r_{i, t}=\ln R_{i, t}$, while $g_{i, t}$ is the natural logarithm of the depreciation adjusted output growth rate, $\left(\mu_{i, t}+\delta\right)$.

For the empirical specification used to test the relationship between economic disasters and aggregate investment suggested by Barro (2009), we introduce the output volatility, volatility and the probability of economic disasters, disasters into the model.

$$
i_{i, t}=\beta+\gamma i_{i, t-1}+\psi g_{i, t}-\sigma r_{i, t}+\theta \text { volatility }_{i, t}+\varphi \text { disasters }_{i, t}+\phi^{\prime} X_{i, t}+\tau_{i}+\eta_{t}+\varepsilon_{i, t}
$$

We also relax the parameter restriction of unity for the coefficient on output growth, $g_{i, t}$, add the lagged dependent variable, $i_{i, t-1}$, to allow for a partial adjustment in the stock of capital (Eberly et al. 2012 and Fiori 2012) and include the vector of additional control variables, $X_{i, t}$. The model includes unobserved country-specific effects, $\tau_{i}$, and the time-specific effects, $\eta_{t}$, while $\varepsilon_{i, t}$ is an idiosyncratic error term.

The econometric analysis of (6) is performed with the Blundell and Bond (1998) system GMM estimation and Lewbel's (2012) estimation. We apply the widely used Blundell and Bond (1998) method to address the issues of endogeneity and dynamic panel bias in dynamic fixed effects model. The time series characteristics of the panel dataset are exploited with this method to generate internal instruments. In particular, the regression equation in differences and the one in levels are merged by the Blundell-Bond system GMM estimator into one system. As a consequence, the instrument matrix becomes composed of two distinct parts. The first part is thus composed of the second and deeper lags of the endogenous explanatory variables in levels, which are used as instruments for the endogenous explanatory variables in the equation specified in first differences. The second part is composed of the second and deeper lags specified in first differences which are used as instruments for the endogenous explanatory variables in the equation defined in levels. Unfortunately, it can be shown that the system GMM estimates can be biased in the case of the weak correlation of instruments and endogenous variables (Bazzi and Clemens 2013). Since the test for weak instruments in the dynamic panel GMM regressions is not currently available, we use an estimation approach suggested by Lewbel's (2012) for the additional check of our results. Lewbel's (2012) estimator allows identification of the structural parameters in regression models with endogenous regressors by using instruments that are constructed as a function of the model's data. Identification is achieved by having regressors that are uncorrelated with the product of heteroscedastic standard errors. In addition to being able to take into account the issue of endogeneity, Almeida et al.'s (2010) simulations show that the instrumental 
variables estimators outperform the standard OLS estimators with respect to the problem of measurement errors in investment equations.

\subsection{Variables and data sample construction}

The Barro's (2009) hypothesis suggests that probability of economic disasters, calculated as the number of economic disasters over the number of years in a considered period, has a long-run negative effect on the savings and hence also the investment rate. Therefore, instead of using country level annual observations we organize the data into country periods. Averaging annual observations reduce the number of observations per country, but it helps to reduce the effect of business cycles variation on our empirical results. This approach to the data sample construction also enables us to better accord with the definition of the probability of economic disasters applied in Barro (2009).

The data on dependent variable are obtained from the World Development Indicators (WDI) database. The WDI provide annual data on the share of aggregate investment in GDP for 203 countries from 1960. Due to data limitations on investment and the other employed variables, we managed to construct an unbalanced panel data for 104 countries from 1960 to 2018. The data are organized into 5 years country periods. ${ }^{5}$, The variable for investment is constructed as logarithm of the average share of aggregate investment in GDP in each country period. The list of all variables, their definition and data sources are provided in "Appendix".

Following the employed neoclassical model, the set of explanatory variables includes the output growth and the cost of capital. The variable for output growth is calculated as logarithm of the average annual growth rate of real GDP. ${ }^{7}$ The cost of capital is proxied by the real interest rate. The variable is constructed as logarithm of the average real interest rate for each country period. The data for both variables are retrieved from the WDI database.

Our main variable of interest is the probability of economic disasters. The literature on economic disasters standardly assumes that this probability corresponds to the observed frequency of economic disasters. In particular, the literature assumes that economic agents' perception of the probability of economic disasters in the future, that affect their current decision making process, is based on the frequency of economic disasters that occurred in the past. This assumption is used in Barro's (2009) study, as well. Hence, in line with Barro's (2009) theoretical model for each country period, we construct our main variable as the ratio of the number of economic disasters to the number of years in a country period. Following Barro and

\footnotetext{
5 1960-1964; 1965-1969; 1970-1974; 1975-1979; 1980-1984; 1985-1989; 1990-1994; 1995-1999; 2000-2004; 2005-2009; 2010-2014; 2015-2018.

6 With respect to the gaps in the data, the following general principle is adopted. In the country periods where one observation for a certain variable is missing, the value of that variable is still calculated. In the cases where more than one observation is missing, the country period is excluded from the analysis.

7 Given that the rate of depreciation is assumed to be constant across countries, adjustment of output growth for depreciation becomes trivial.
} 
Ursúa (2008, 2012), we consider economic disasters as country-specific economic crises defined as a cumulative decline in output over one or more years of at least 10 percent. The country level data on economic disasters since 1950 are obtained from the new dataset on economic disasters constructed by Ćorić (2020). In the country periods without detected economic disasters, the value of our variable is zero by construction. Therefore, since we use the logarithm specification of our model, the variable for economic disasters employed in the model is calculated as a logarithm of one plus the probability of economic disasters.

Construction of the variable for economic disasters raises the question as to what is an appropriate time span for construction of the country period data. More precisely, it raises the question how long a time span should be used to calculate the probability of an economic disaster. The simplest approach is to follow Barro (2009) and use the entire time span for which the data are available for each country. In this case, however, we lose the time series dimension of our data set. Consequently, we lose the possibility to analyze a potentially valuable source of information, the within-country variations in the data. On the other hand, since economic disasters are relatively rare events the standardly used time spans in the empirical literature of 1,5 or 10 years are not appropriate in this case. Namely, economic disasters would be absent in most of the country periods implying that economic agents' perception of the probability of economic disasters for most country periods is zero. Therefore, the data for economic disasters are organized in the overlapping thirty-year periods. ${ }^{8}$ The employed approach results in the average value of the probability of economic disasters in our data sample being 0.023 .

In this respect, our approach to the construction of the probabilities of economic disasters is more conservative compared to the approach used by the current literature. Particularly, almost all studies in this literature have been using Barro and Ursúa's $(2008,2012)$ data on economic disasters. These estimates are based on their historical output data for 42 countries over the last two centuries. ${ }^{9}$ Accordingly, the used probabilities of economic disasters for each country are calculated over its entire recorded economic history, that is, over 100 or more years that yields the average probability of economic disasters of about 0.036 . Due to the limited historical data on investment and the employed explanatory variables, our analysis is restricted to the post-WWII period. The shorter time period makes our estimates on economic disasters more conservative because in our study the economic agents' perception of the probability of economic disasters is based on the frequency of economic disasters over the last 30 years. In other words, due to the data sample construction, economic disasters that occurred more than 30 years ago do not have any effect on the current investment decisions in our specification. ${ }^{10}$

\footnotetext{
8 1950-1979; 1955-1984; 1960-1989; 1965-1994; 1970-1999; 1975-2004; 1980-2009; 1985-2014.

9 The data are available up to 2009 while country starting dates vary, ranging from 1790 for the United States to 1911 for Korea and South Africa.

10 Please note that our organization of the data on economic disasters into the overlapping periods also does not work in favor of our empirical estimates of the hypothesized negative effect on investment, because it smooths out the within-country variations in our main explanatory variable.
} 
Since in the AK model constructed by Barro (2009), the effect of output volatility on investment works through the same channel as the effect of economic disasters, the variable for output volatility is also organized in the overlapping thirty-year periods. The variable is constructed as logarithm of the standard deviation of annual output growth rates. The output growth rates are based on annual data on real GDP from the WDI database.

To account for possible alternative determinants of investment, a number of control variables are included in the analysis. The control variables are suggested by previous studies that explore various aspects of investment (see, for example, Ndikumana 2005; Bond and Malik 2009; Dearmon and Grier 2011; Fatica 2018; Alves 2019). All control variables are organized in 5 years country periods. The set of control variables includes: population (constructed as logarithm of the average annual population growth), trade openness (defined as logarithm of the average value of the sum of exports and imports as a share of GDP), financial openness (constructed as logarithm of the average value of cross-border holdings of assets and liabilities as a share of GDP), credit to private sector (defined as logarithm of the average value of the domestic credit to private sector as a share of GDP), government consumption (created as logarithm of the average value of general government final consumption expenditure as a share of GDP), secondary education (defined as logarithm of completed secondary education) and the relative price of capital (constructed as logarithm of the average value of the ratio of price of investment to the price of GDP). The definition of these variables and sources for these data are reported in "Appendix" (Table 3).

\section{Results}

Table 1 reports the Blundell and Bond (1998) system GMM estimates of our panel regression model. In our specifications, all explanatory variables are treated as endogenous. The (orthogonalized) instrument matrix includes the second and deeper lags of the explanatory variables and economic disasters organized in twenty-year periods. Following Roodman (2009), the instrument set collapsed to keep the number of instruments lower than the number of groups (countries). The reported standard errors are corrected to account for heteroscedasticity and the arbitrary patterns of autocorrelation within countries. The issue of potential cross-country correlation, due to the spillover of investment and/or unobserved common factors, is addressed by time dummies. The results of Pesaran's (2015) test indicate that our panel models are well specified as statistical models with respect to cross-sectional dependence. The Arellano-Bond AR(2) test suggests that the second-order serial correlation in the first-differenced errors is rejected at the standard 5 percent level of statistical significance, while the Hansen test exceeds the conventional threshold in all models. Column 1 reports the results of our benchmark model. Since introduction of control variables changes the sample size, due to the missing data, we first add the control variables to the benchmark model separately (columns 2-8). In the last column of Table 1, we report the results of the fully specified model. The comparison between these regressions provides two internal robustness checks. First, the comparison 


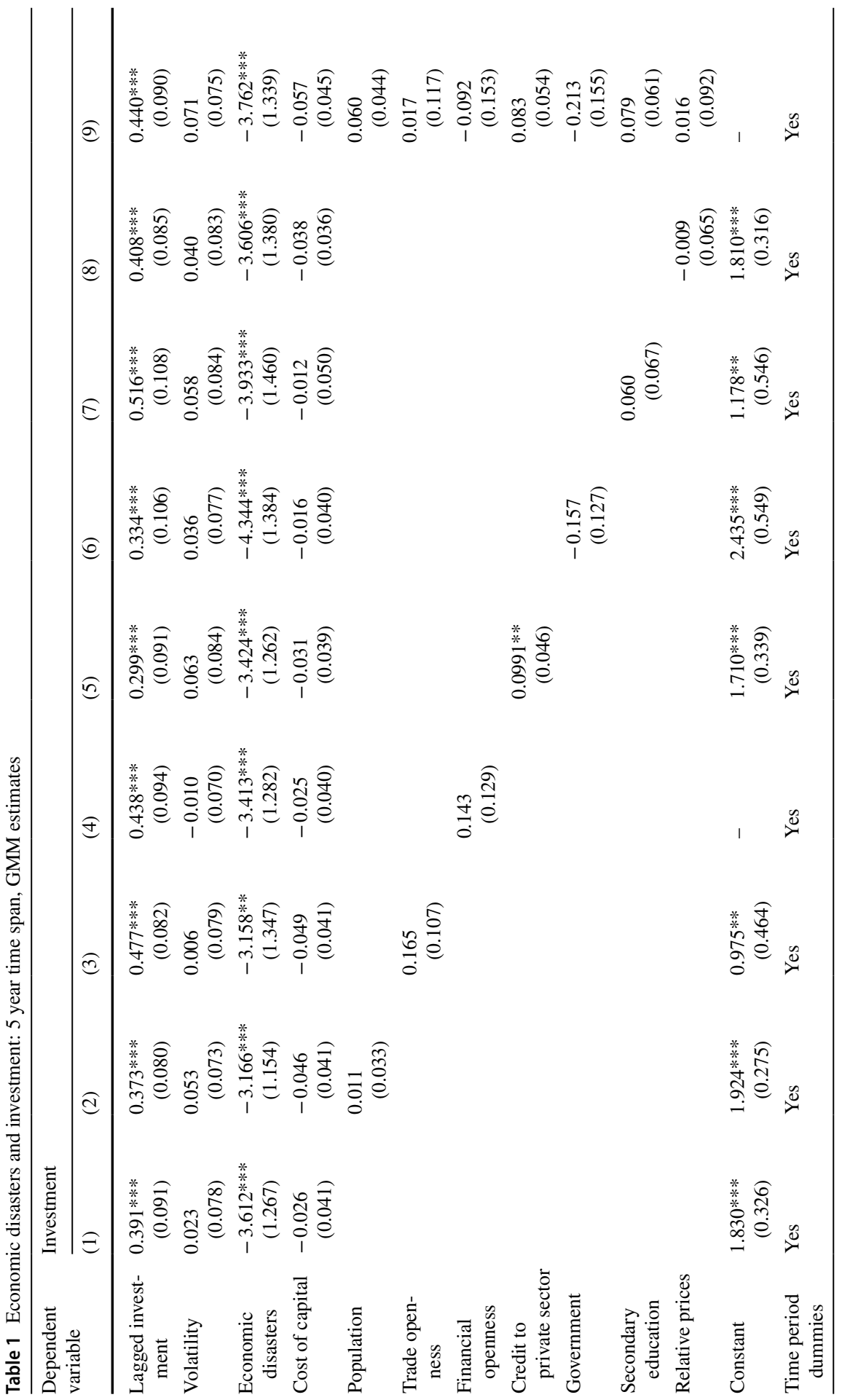

\section{글 Springer}




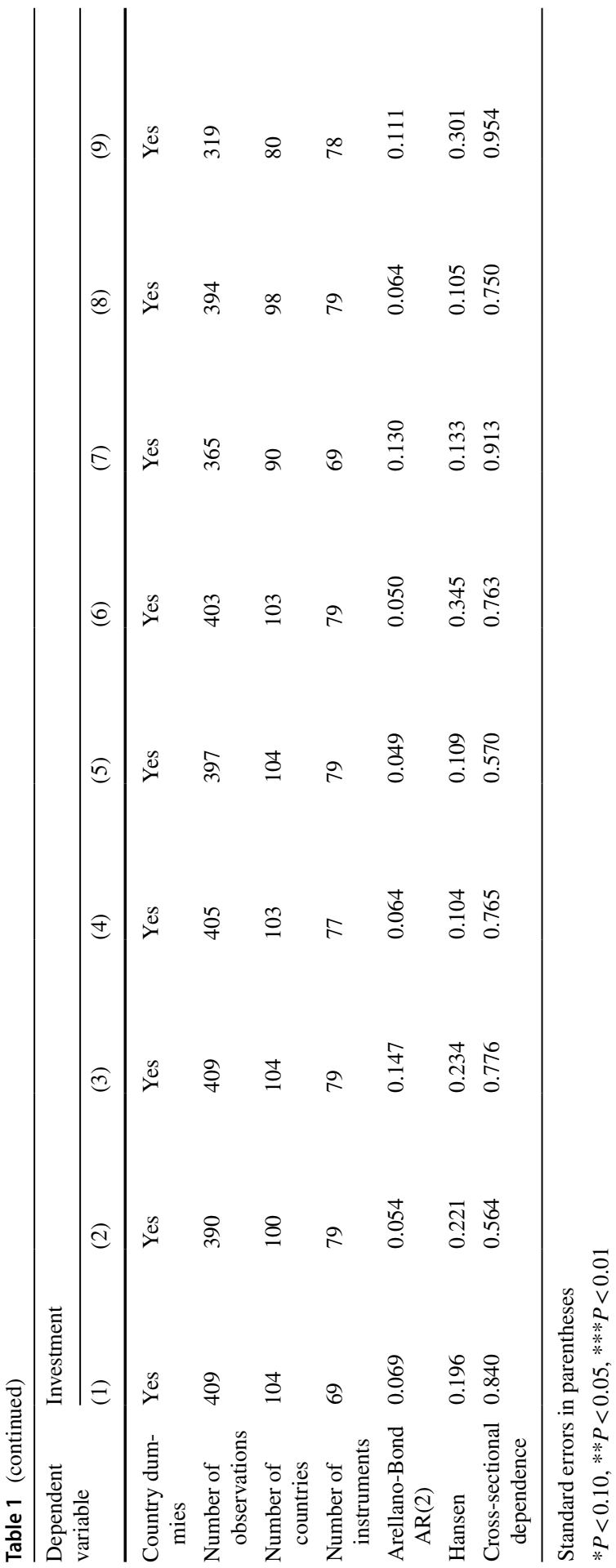


shows that the results related to our variable of interest are not substantially influenced by the specification of our model: the reported signs are uniformly negative, the size of the estimated coefficients and the levels of statistical significance vary little. Secondly, since the missing data dictate that the number of observations in the sample varies with the number of included control variables, the comparison confirms the robustness of our estimated effects of economic disasters with respect to the reported changes in the sample size.

The estimated coefficients in our benchmark specification (column 1) are mostly in line with prior theoretical expectations. In particular, consistently with the standard neoclassical model (Hall and Jorgenson 1967) and the investment adjustment costs model (Christiano et al. 2005; Eberly et al. 2012; Fiori 2012) the coefficients on output growth and lagged investment are positive and statistically significant. The coefficient on the cost of capital (proxied by the real interest rate) appears to be negative as expected but statistically insignificant. This result seems to be in accordance with a broader literature (see for example Caballero 1999; Chirinko 2008; Fatica 2018) which also struggled to find a robust empirical effect of the cost of capital on aggregate investment. The results reported in columns 2-9 show that the coefficients on the above variables remain robust with respect to the sign, size and statistical significance when the control variables are included in our benchmark model.

The coefficients on our main variable of interest across all specifications (columns 1-9) reveal a negative and statistically significant relationship between probability of economic disasters and the share of aggregate investment in GDP. The estimated coefficient on economic disasters appears to be relatively large in absolute values. In contrast to this, the corresponding coefficients on output volatility are relatively small and statistically insignificant in all reported models. Thus, our results provide empirical support to the negative long-run effect of the probability of economic disasters on aggregate investment proposed by Barro (2009). Furthermore, our results on economic disasters and output volatility taken together are consistent with the results of the empirical simulations of the Barro's (2009) AK model which suggest that the main negative effect of uncertainty on investment is related to the probability of economic disasters, while the effect of uncertainty related to the "normal' output volatility is negligible.

However, as noted above the system GMM estimates can be biased due to the weak instruments problem. Therefore, we now turn to the Lewbel's (2012) method to estimate the models reported in Table $1 .^{11}$ Since the Lewbel's (2012) estimator does not address the problem of the dynamic panel bias instead of the country dummies we introduce a set of time-invariant geographic covariates into the models. Thus, following Bond and Malik (2009) and Isham et al. (2005) we include the following dummy variables: dummy for landlocked countries; a set of regional dummies (East Asia and Pacific, Middle East and North Africa, South Asia, etc.); dummy for fuel exporting countries; and the dummy variable for countries with coffee and cocoa resources. In the model, we also include the variable called distance to

11 The method is implemented by using the ivregh2 Stata module which allows application of the Lewbel's (2012) estimator in panel data regressions (Baum and Lwebel 2020). 
the market (country distance to the nearest market-Europe, US and Japan). Detailed definition of these variables and sources for the data are provided in "Appendix" in Table 3 .

Table 2 reports the results of the Lewbel's (2012) estimates. In all models, the variable for economic disasters is instrumented with the first lags of economic disasters constructed over the thirty and twenty years time periods and instruments generated by the Lewbel's (2012) method. The reported standard errors are robust to heteroscedasticity. The results of Pesaran's (2015) tests do not indicate problems of cross-sectional dependence. The values of the Hansen test and C statistics suggest that the instruments are uncorrelated with the error term. The Kleibergen and Paap's (2006) test statistic shows that the null hypothesis of zero correlation between instruments and endogenous variable can be rejected at conventional levels of significance. The Kleibergen-Paap rk Wald $F$ statistic comfortably exceeds the conventional threshold in all models, indicating that the null of weak correlation of instruments and endogenous variable can also be rejected. ${ }^{12}$

The estimates reported in Table 2 show that the coefficients on our main variable of interest remain negative and statistically significant in all specifications. The size of the coefficients is however reduced. Even so, the estimated long-run effect of economic disasters on investment is still relatively large with the size of the coefficient on economic disasters in the fully specified model being -1.04 , suggesting that a $1 \%$ increase in probability of economic disasters decreases the share of investment in GDP by $2.76 \%$. To provide a rough illustration of the meaning of this effect, let us state that the $10 \%$ decrease in the probability of economic disasters (say, from its average $2.21 \%$ to $1.98 \%$ ) results in an increase in the share of investment in GDP of $27.63 \%$ (say, from the average share of $23.11 \%$ to $29.49 \%$ ). Hence, the effect of economic disasters on investment appears to be economically relevant. With respect to other explanatory variables, the Lewbel's (2012) estimates tend to give the coefficients with higher levels of statistical significance compared to the results reported in Table 1. However, these variables are not considered as an endogenous in the estimates reported in Table 2.

To additionally test the robustness of our results, we employ a set of alternative controls. As an alternative measure for financial development, we employ the credit provided by financial sector from the WDI database. From Gygli et al. (2019), the KOF index of trade globalization has been used as an alternative indicator for trade openness, while the KOF index of financial globalization has been used instead of the previously used indicator on financial openness. For the level of human capital, we use three alternative measures: secondary education total and the average years of schooling from Barro and Lee (2013) and the level of human capital from PWT. We also introduce an additional variable tax revenue (tax revenue as a share

\footnotetext{
12 Since the Cragg-Donald Wald $F$ statistic is not robust to heteroscedasticity Baum et al. (2007) suggest reporting the Kleibergen-Paap $r k$ Wald $F$ statistic for the weak identification when i.i.d. residuals are not assumed. Because the Stock and Yogo's (2005) tabulated critical values are calculated for the case of i.i.d. residuals, they also suggest application of the older "rule of thumb" indicating that the $F$ statistic should be at least 10 for weak identification not to be considered as a problem.
} 


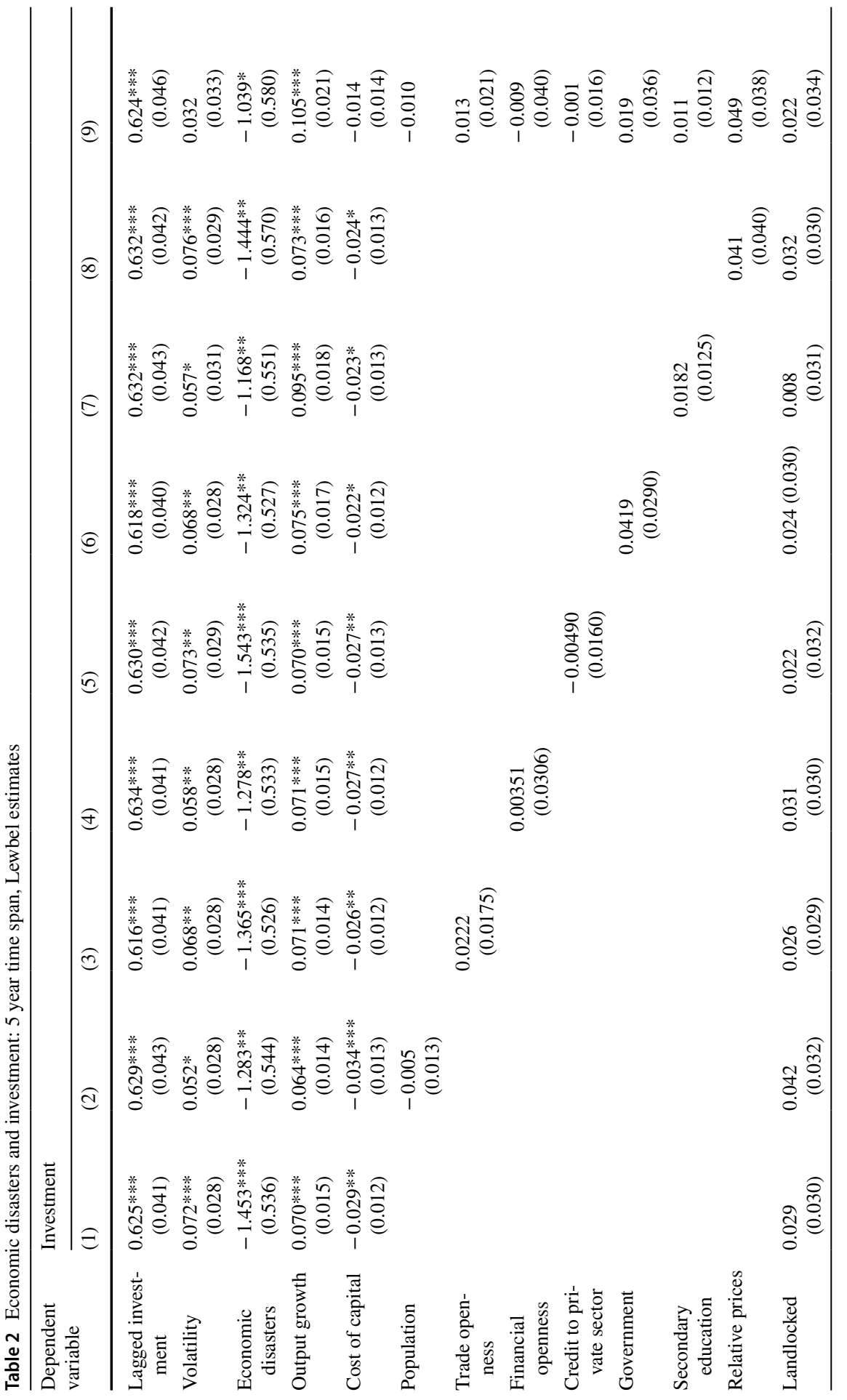

\section{글 Springer}




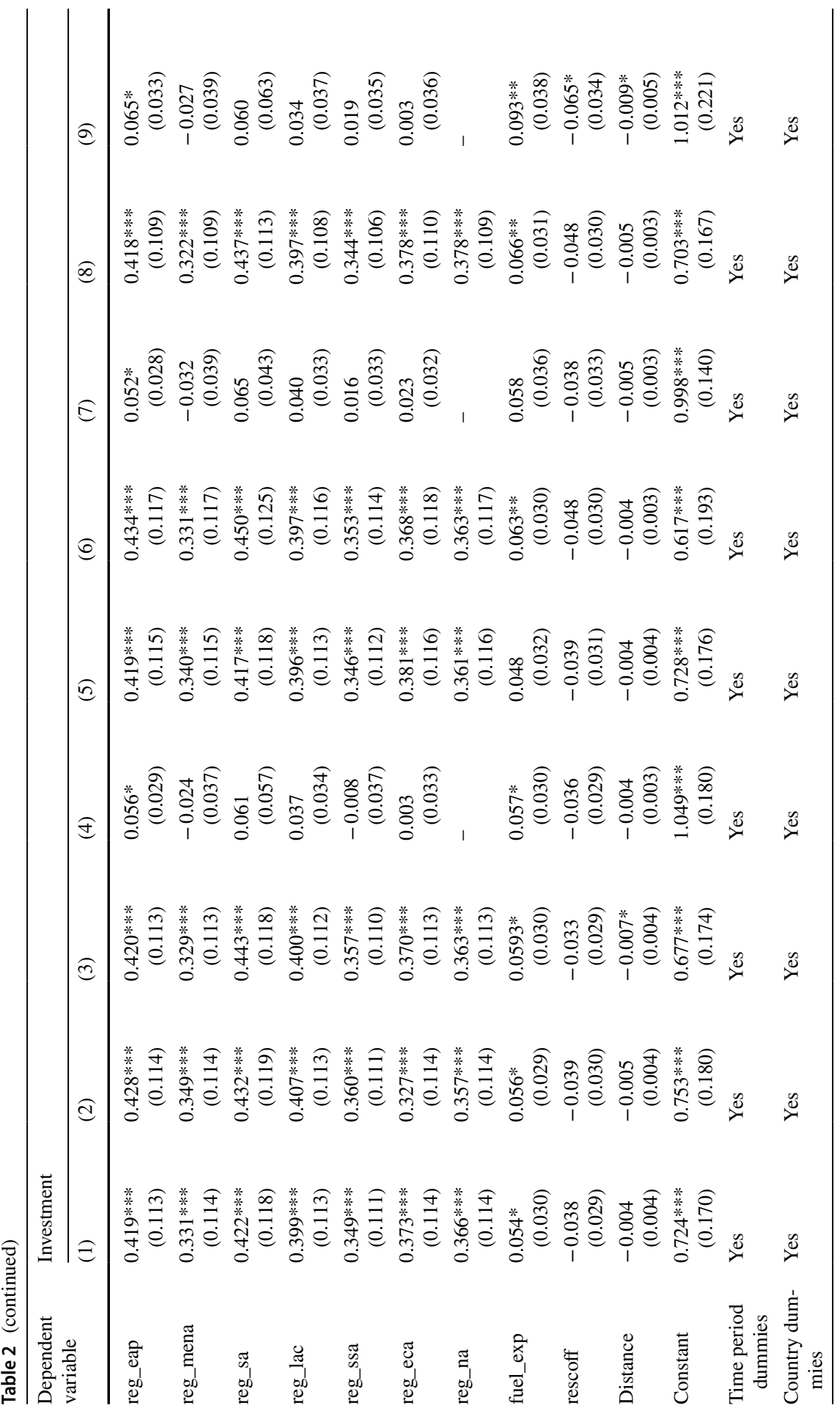




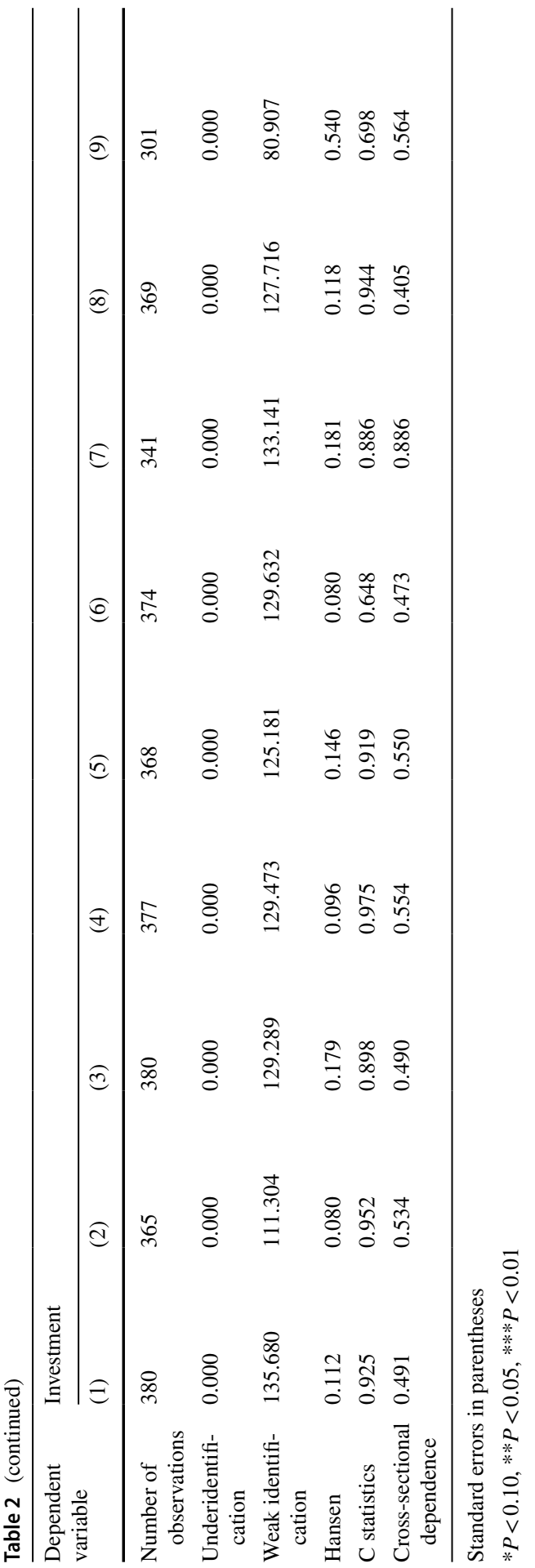


of GDP) to test the possibility that investment might be also affected by taxation (Alves 2019). As previously done, all variables are constructed as logarithms.

Each variable is introduced separately in our benchmark model. For each specification, we report the Blundell-Bond (1998) system GMM estimates ("Appendix" Table 4) and Lewbel's (2012) estimates ("Appendix" Table 3). The reported coefficients on economic disasters appear to be consistent with the estimates in Tables 1 and 2. The only exception is the result in column 2 of Table 5 where the coefficient on economic disasters appears to be insignificant. However, due to data limitations on the tax revenues variable, the number of observations in this specification is substantially lower compared to the other specifications. The coefficients on output volatility, output growth, cost of capital and lagged investment also remain in line with the estimates reported in Tables 1 and 2 with respect to the sign, size and statistical significance.

Our research aims to investigate the long-run effect of economic disasters on investment. To address the concern that the used 5 years averages of data are not long enough to ameliorate the effect of business cycles variation, we construct an additional data sample in which the data are organized into the 10 years periods. The estimates obtained by using this data sample are reported in "Appendix" (Tables 6, $7,8,9)$. Averaging the data into 10 years country periods substantially reduce the number of observations. Nonetheless, the results on economic disasters and other variables remain robust with respect to the sign, size and statistical significance. In particular, the estimated effects of economic disasters on investment are all negative and of a similar size compared to the corresponding estimates obtained by using the main data sample. The reported coefficients appear to be statistically significant in 30 out of 32 specifications.

\section{Conclusion}

This paper contributes to a better understanding of the long-run relationship between economic disasters and aggregate investment. Namely, severity of the recent financial (economic) crisis and the burst of economic and political uncertainty it created around the world inspired a growing research on the effects of rare but extremely large economic crisis (e.g., Barro 2006; Barro and Ursúa 2012; Gabaix 2012; Gourio 2013; Wachter 2013; Isore and Szczerbowicz 2015; Barro and Liao 2016; Farhi and Gabaix 2016; Rebelo et al. 2018 and Seo and Wachter 2019).

This paper empirically investigates the negative long-run effect of economic disasters on investment suggested by Barro (2009). The contribution of the paper is a construction of a large dataset on investment of above one hundred countries and employment of a new dataset on economic disasters across the world after the WWII (Ćorić 2020). Results of the conducted panel regression analysis reveal a negative long-run relationship between the probability of economic disasters and aggregate investment. The used instrumental variable estimates suggest that this effect is unlikely to be driven by endogeneity only. The estimated negative effect appears to be relatively large suggesting that the long-run effect of economic disasters on aggregate investment is economically important. Additional checks indicate that 
this finding is robust with respect to variations in the model specification and corresponding variations in the sample size, different estimation techniques and an alternative construction of the data sample. Consistently with Barro (2009) model our estimates do not reveal a substantial long-run causal effect of the 'normal' output volatility on aggregate investment. The estimated causal effect of output volatility on aggregate investment appears to be relatively small and statistically insignificant.

Thus, our research provides empirical support to the Barro's (2009) hypothesis that the main long-run negative effect of uncertainty caused by variations in output on investment is related to the probability of economic disasters, whereas the effect of uncertainty associated with the 'normal' output volatility is relatively small.

\section{Appendix}

See Tables 3, 4, 5, 6, 7, 8, 9 . 


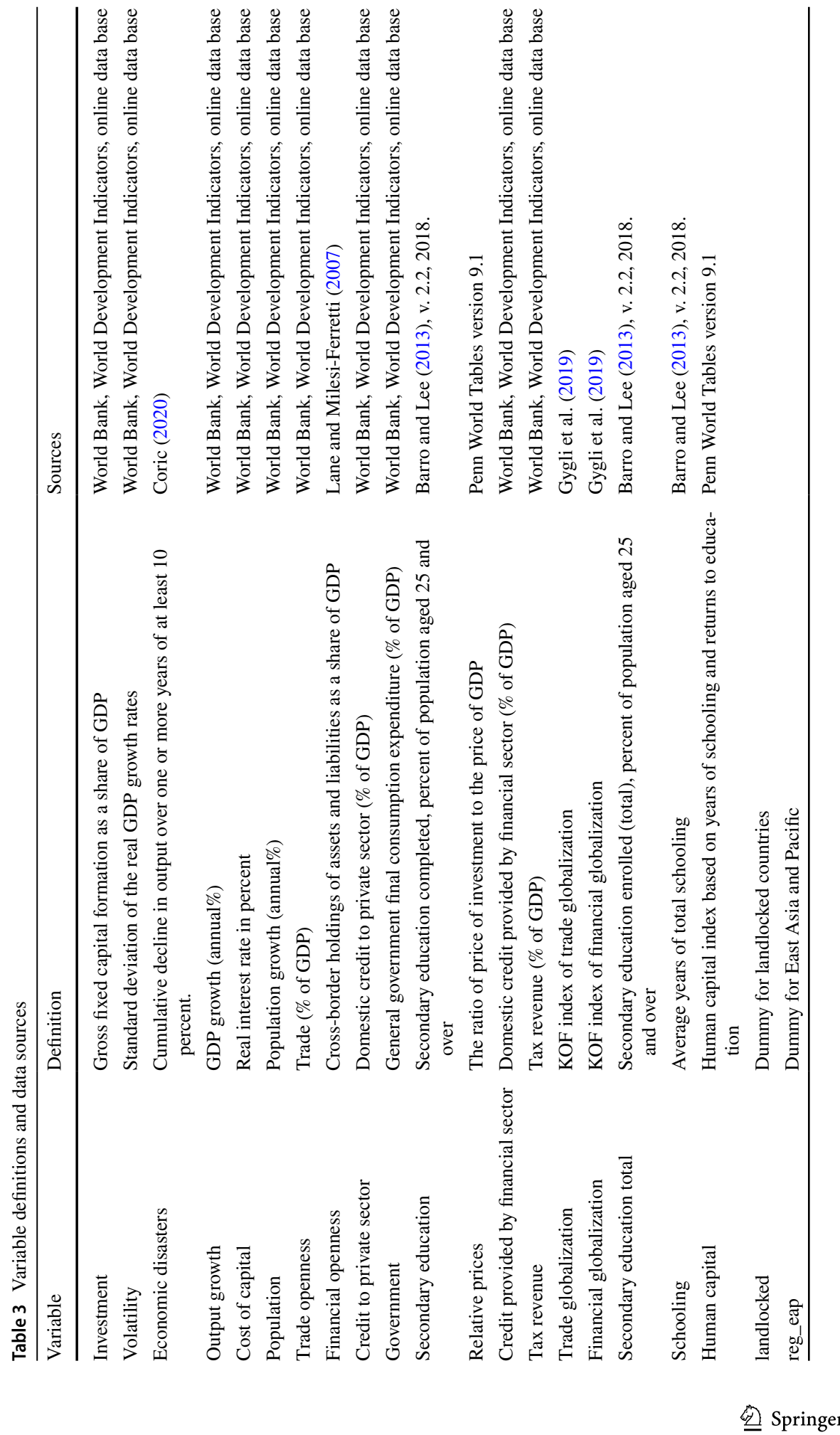




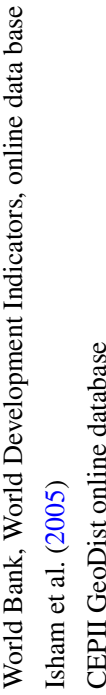

t

5

ڤั.

氙

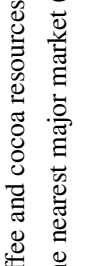

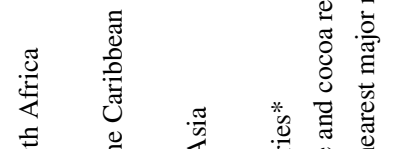

후

.

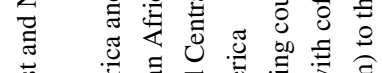

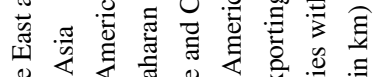

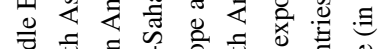

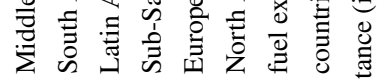

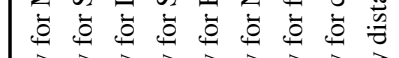

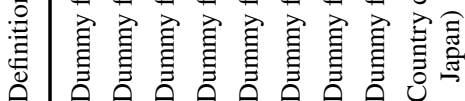

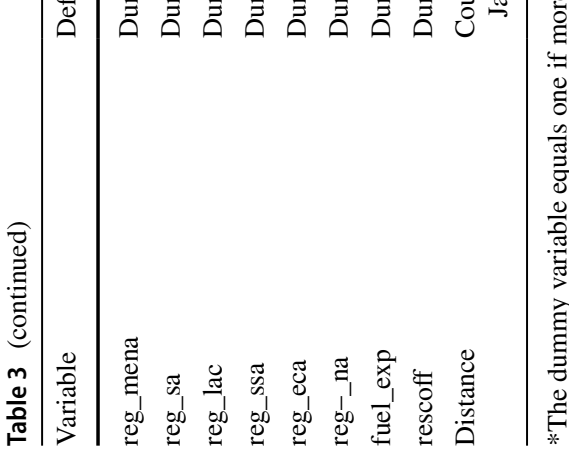




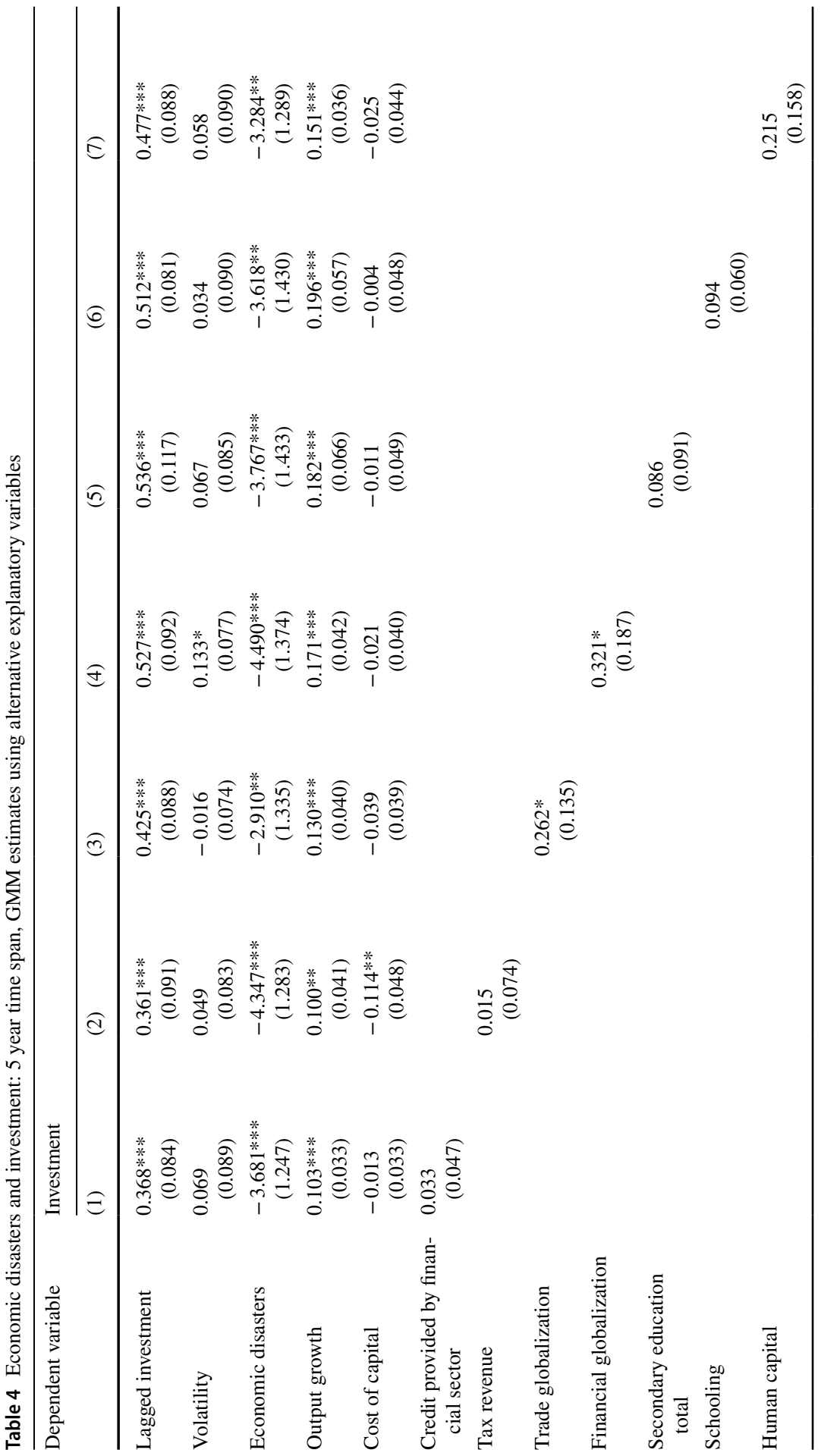




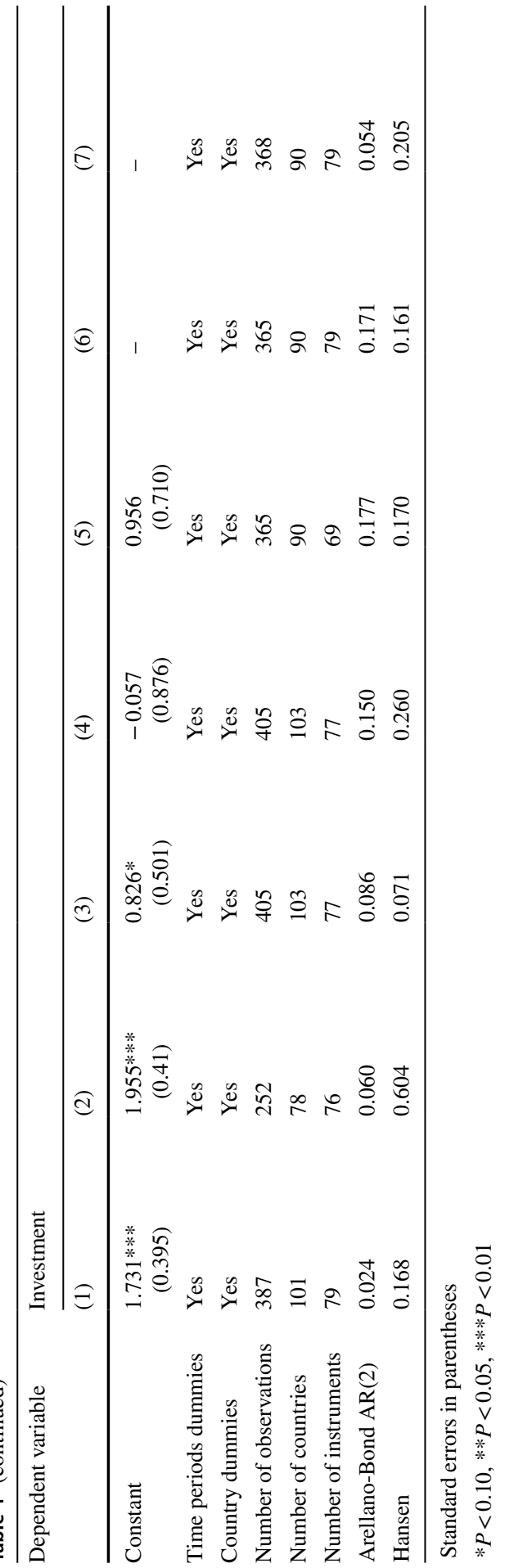




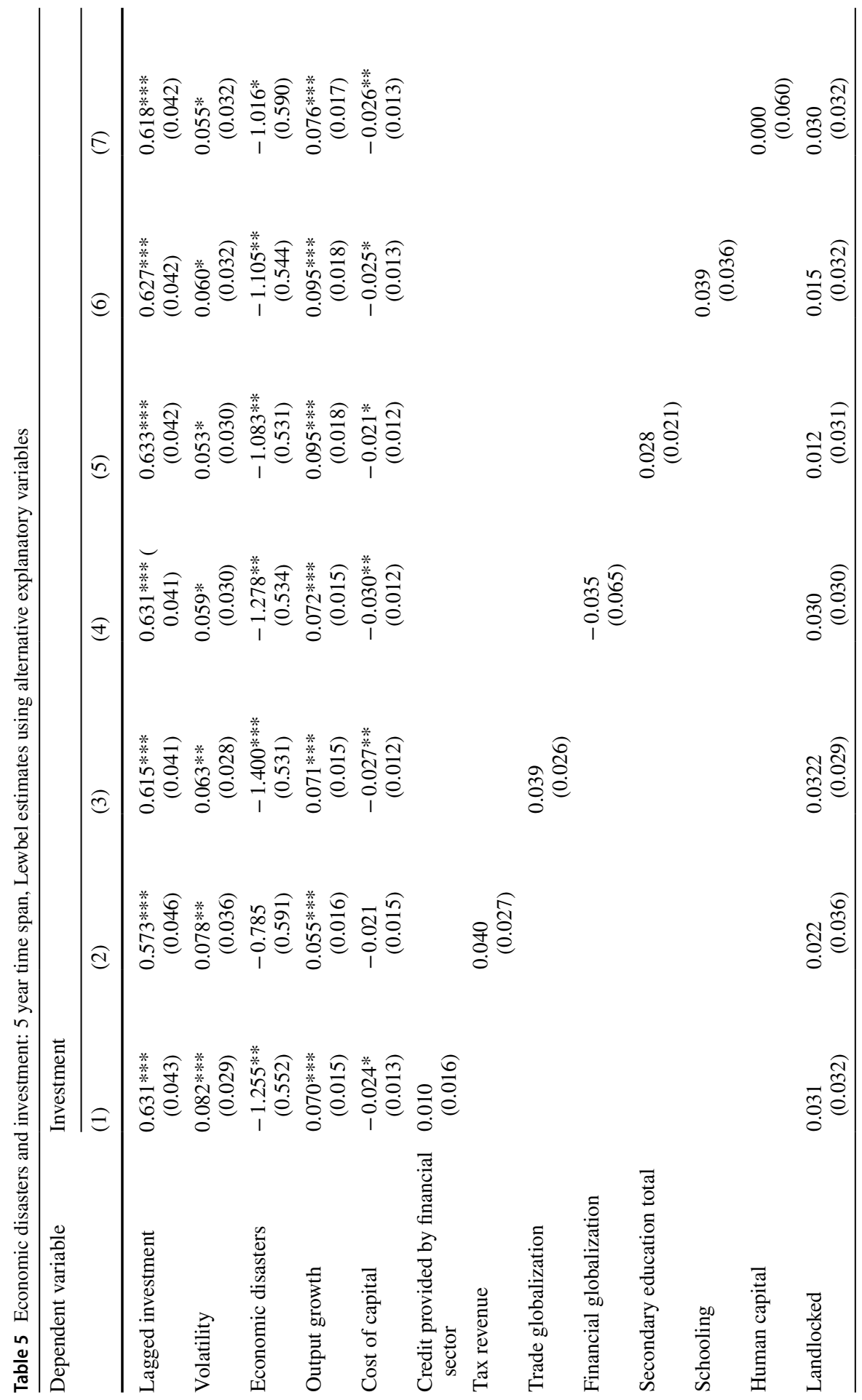




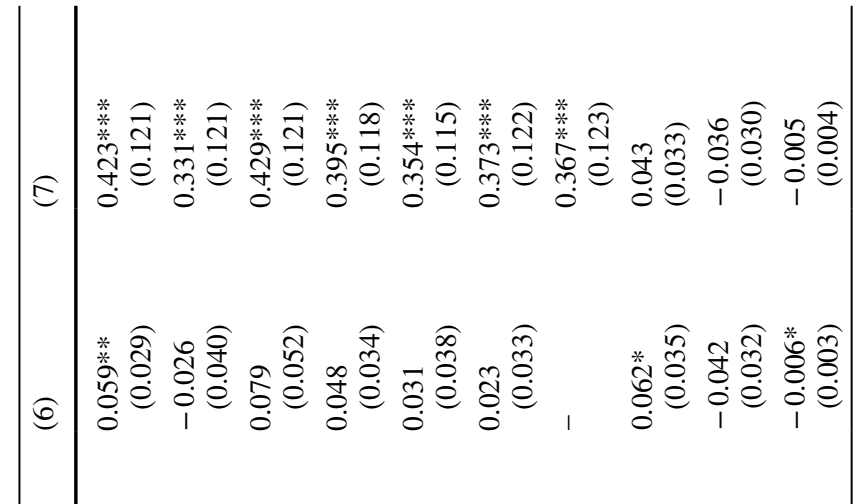

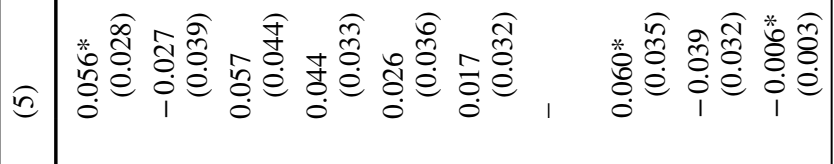

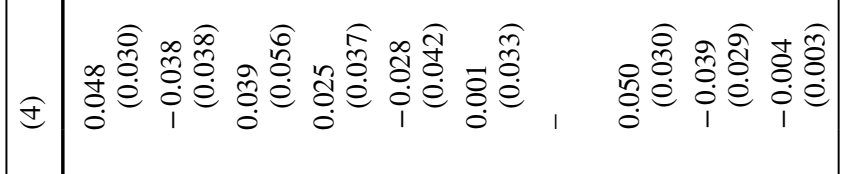

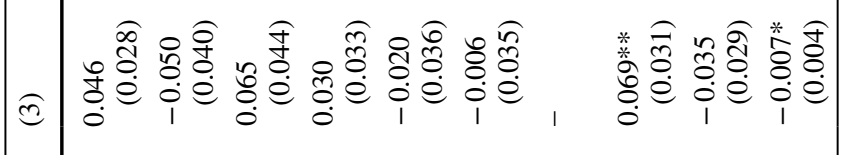

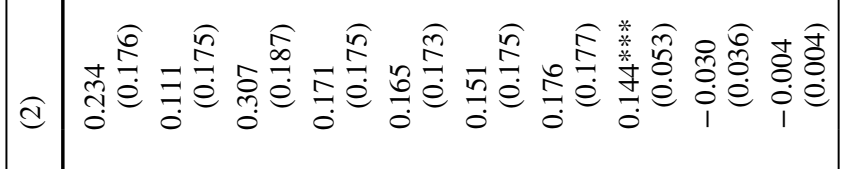

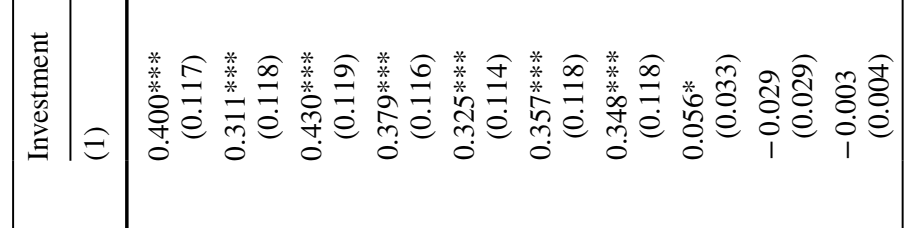

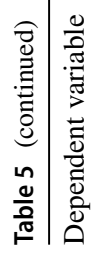

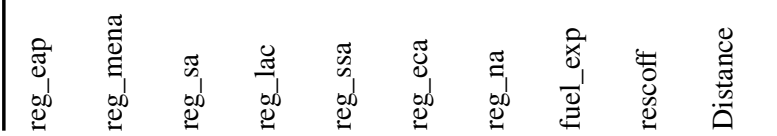




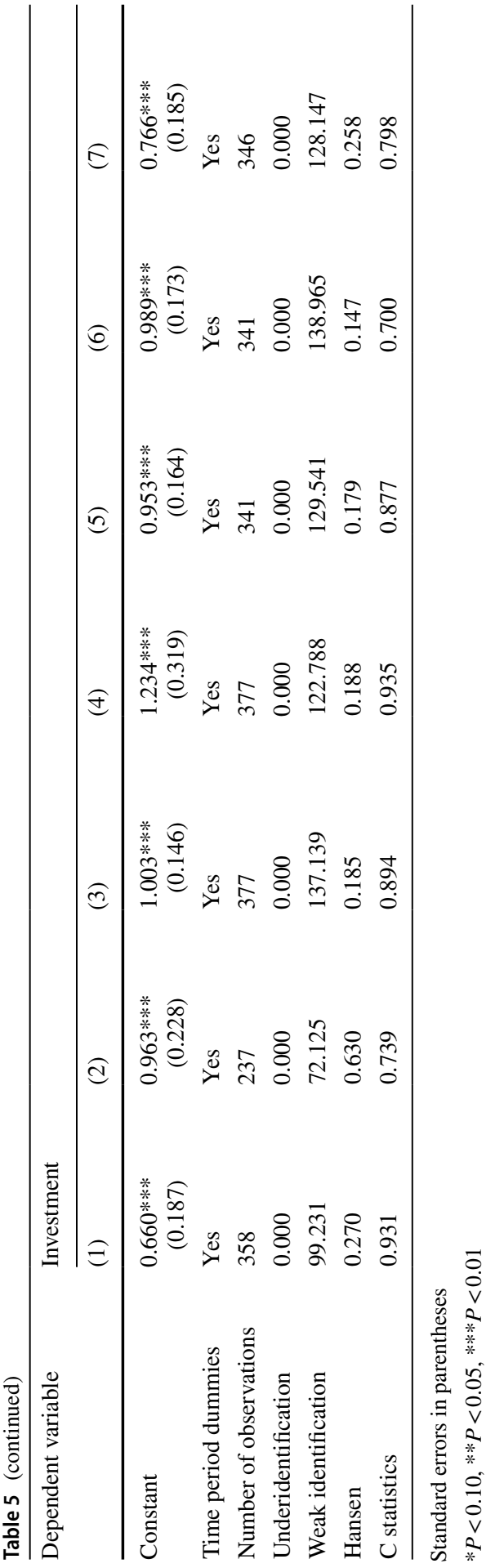




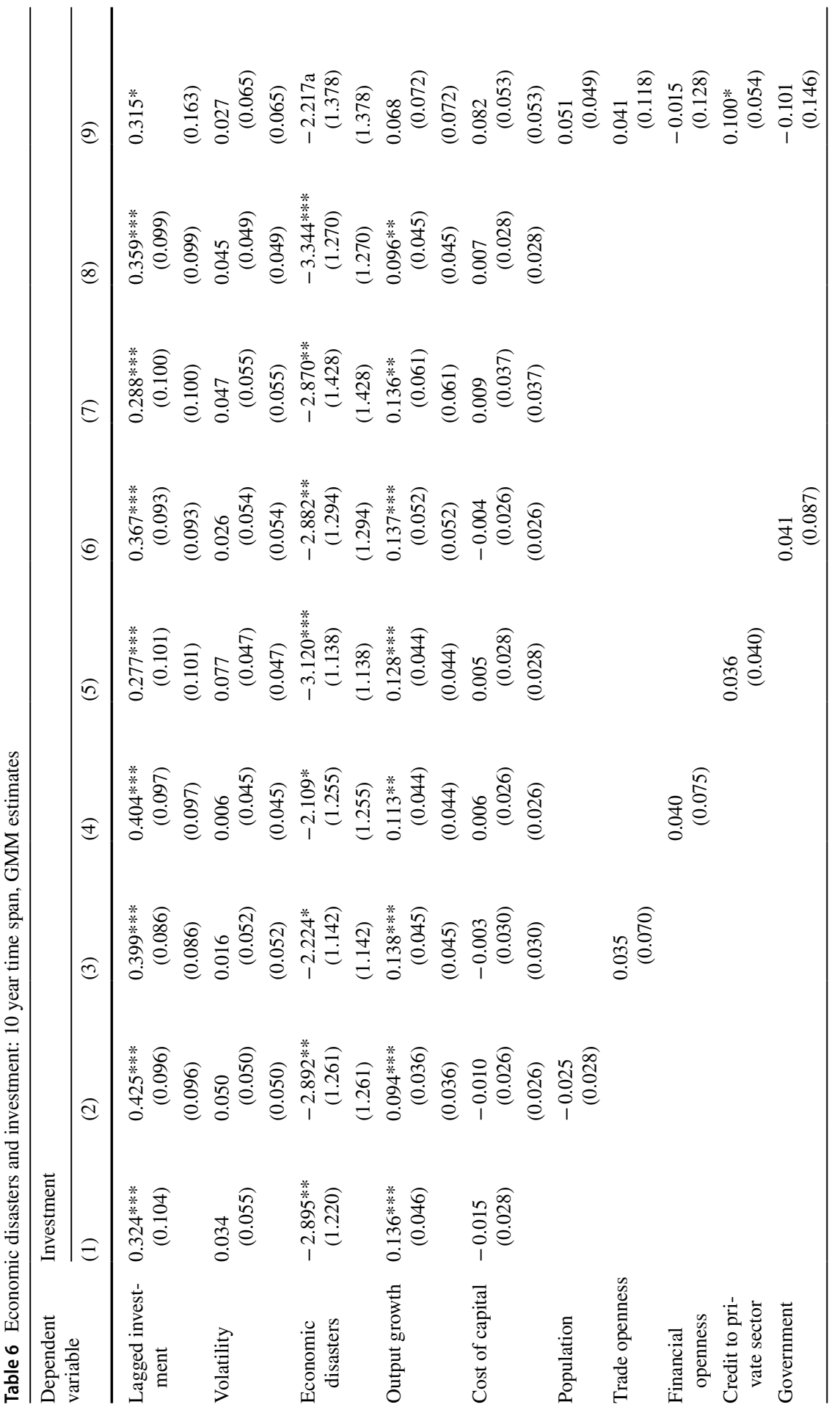




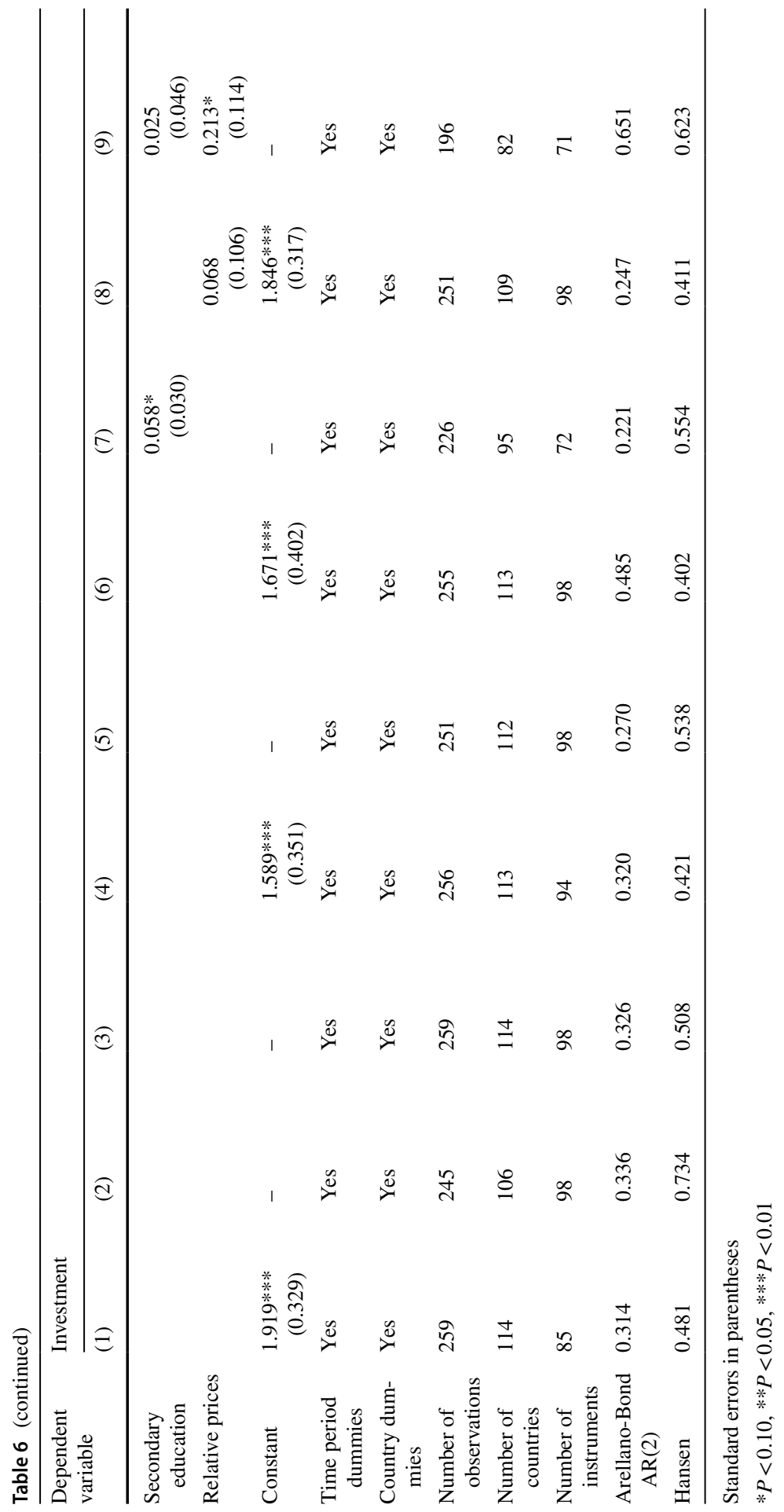




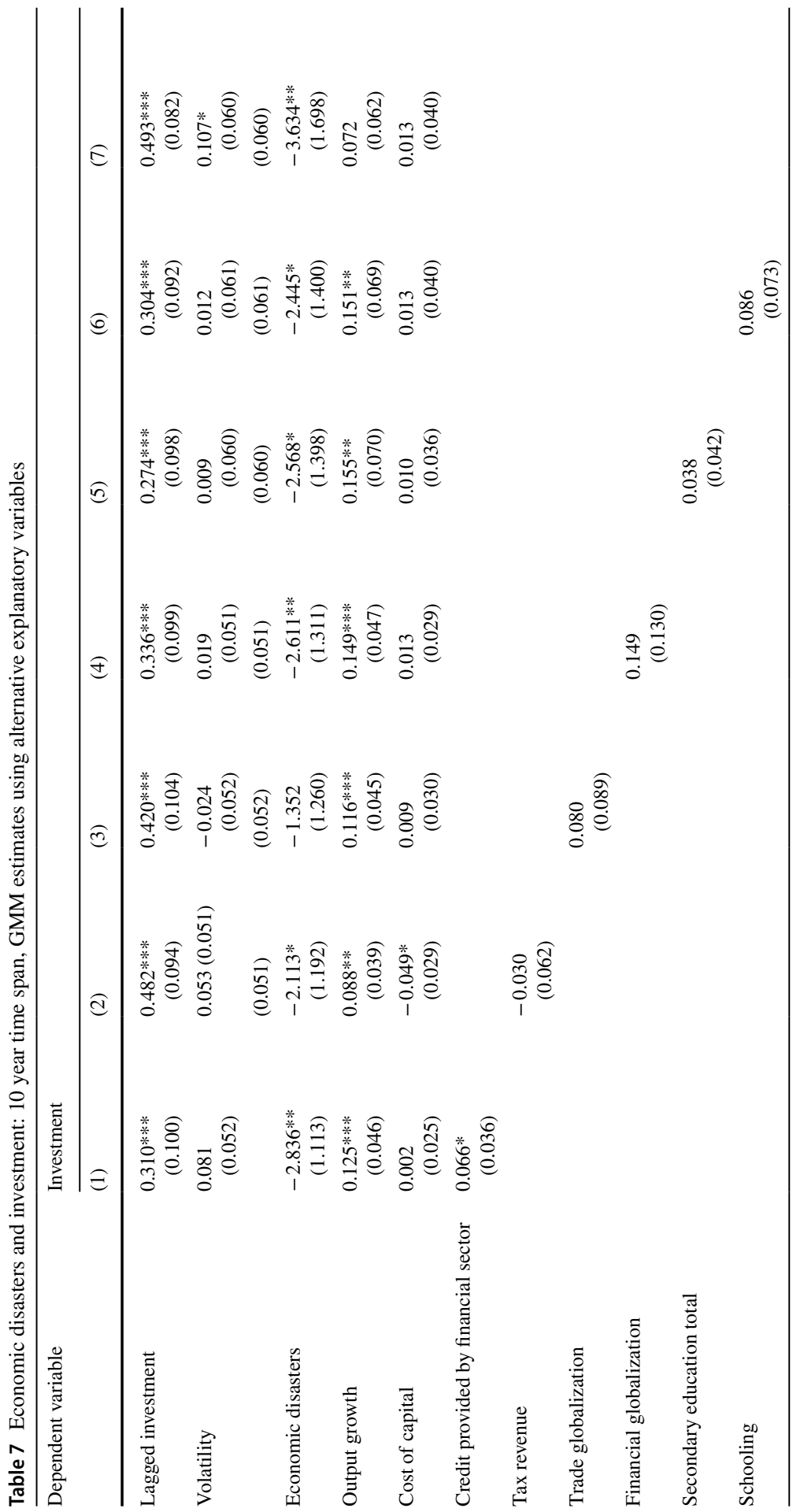




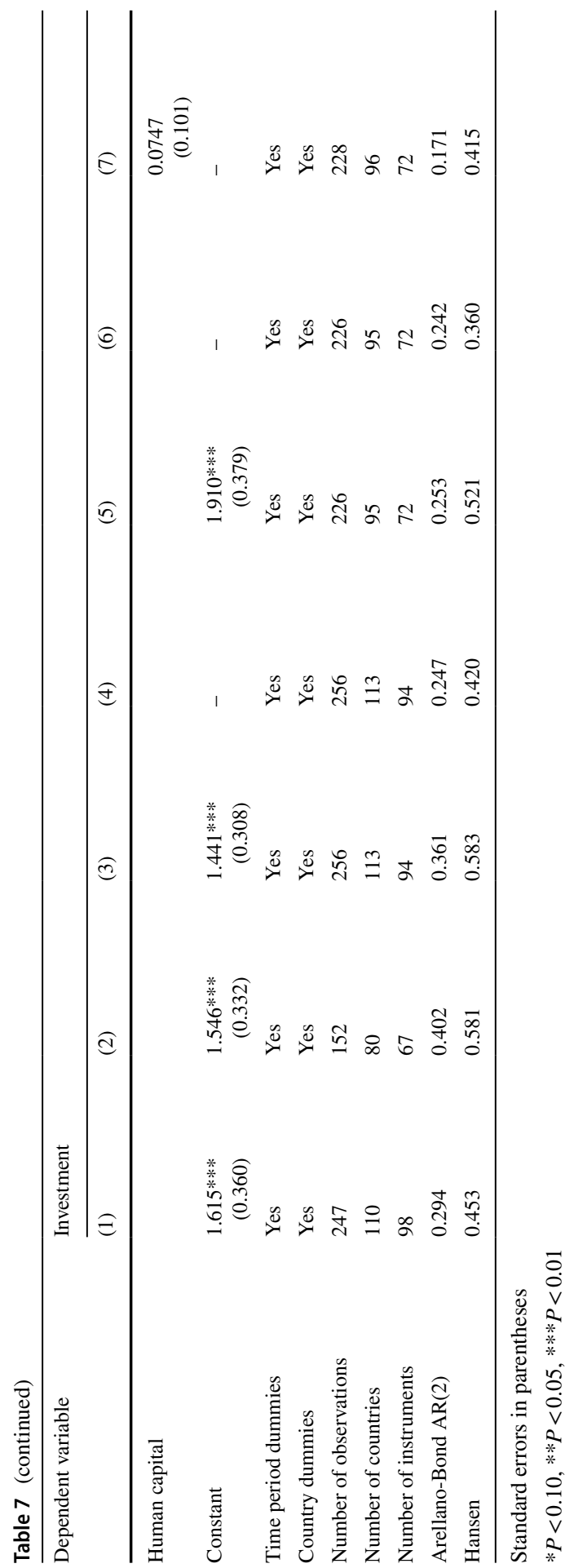




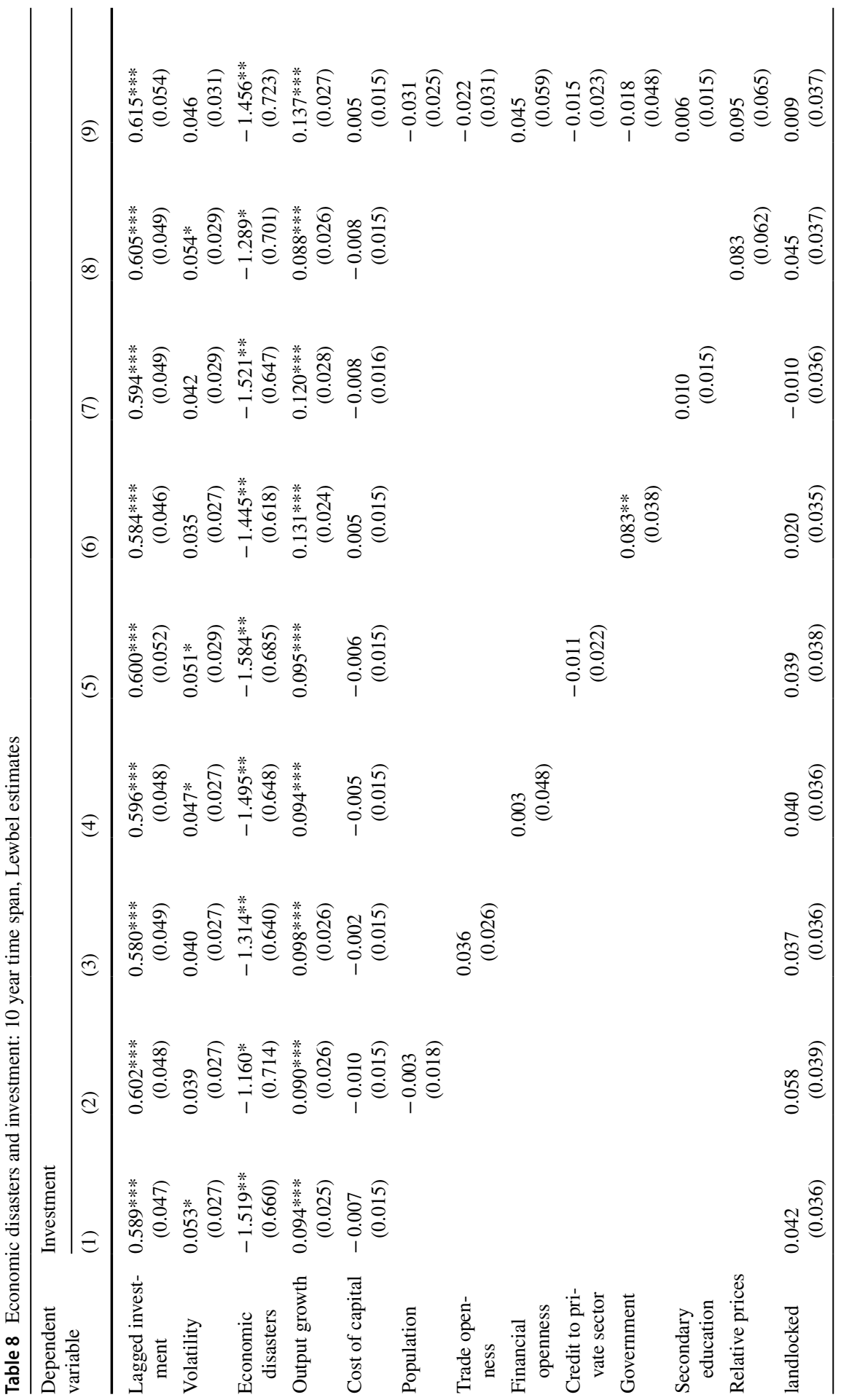




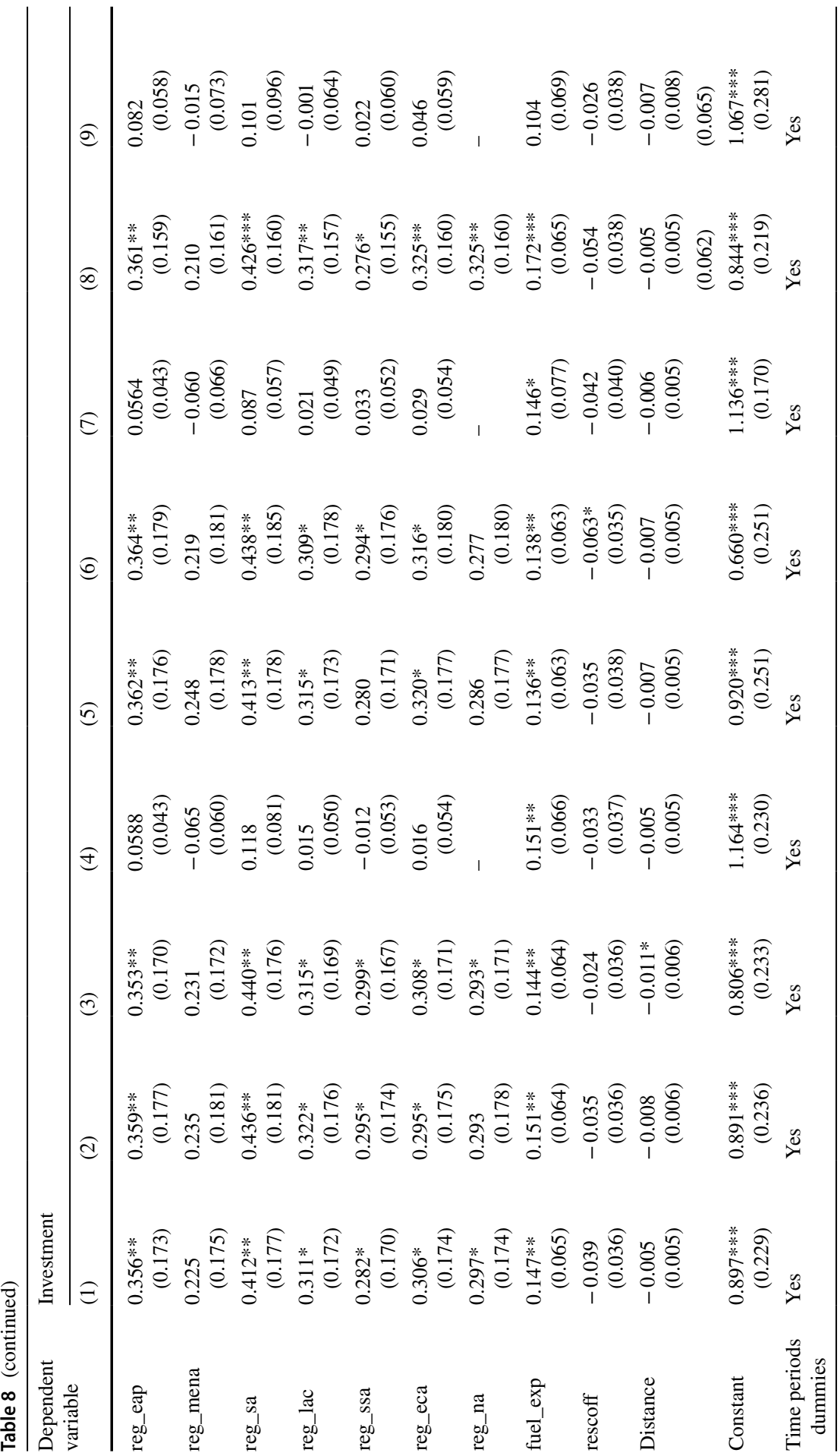




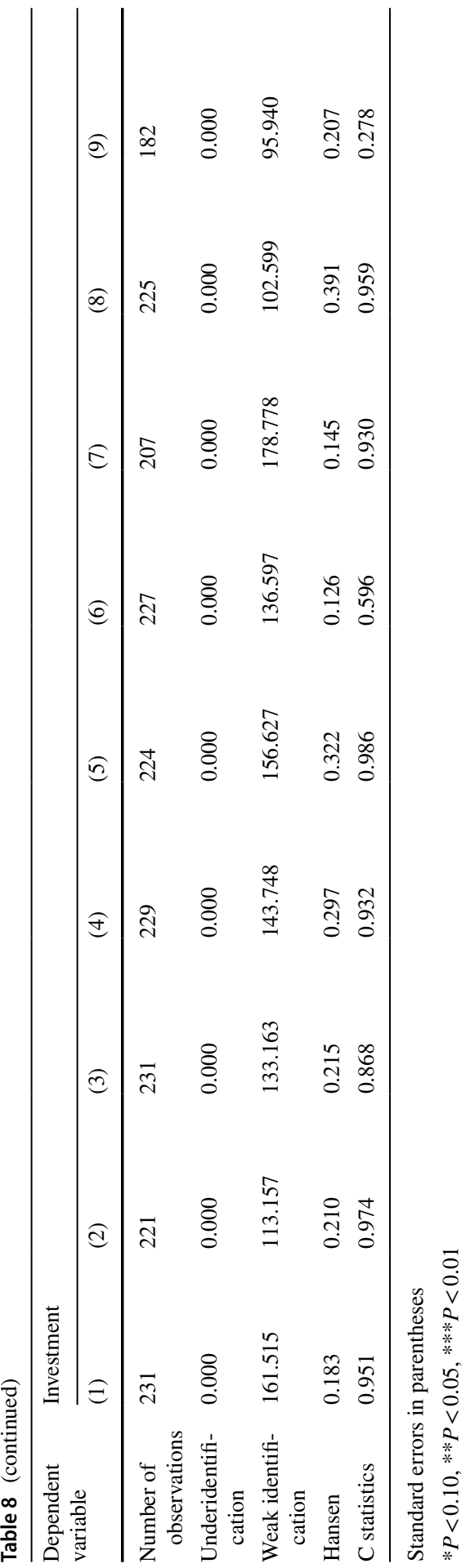




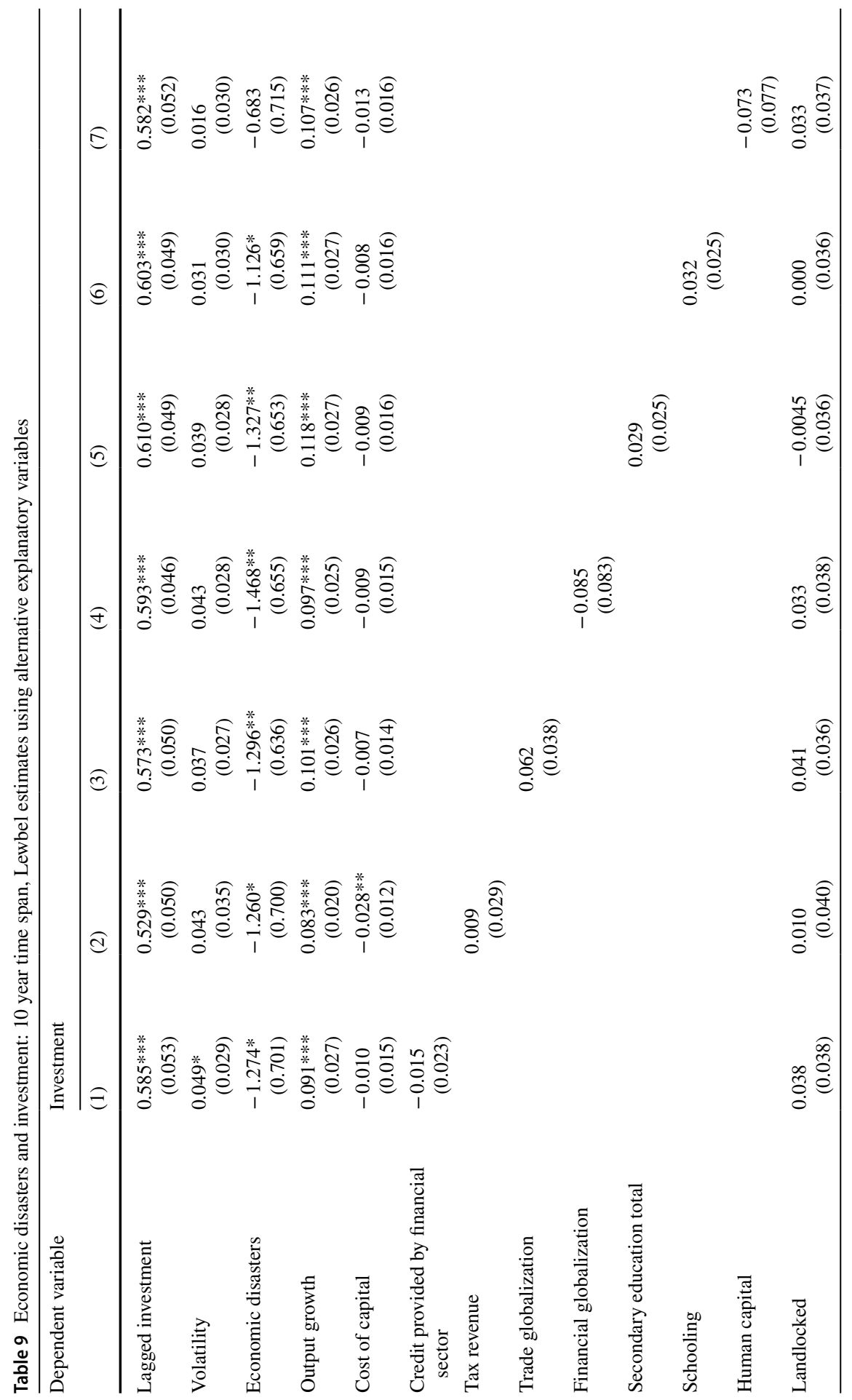




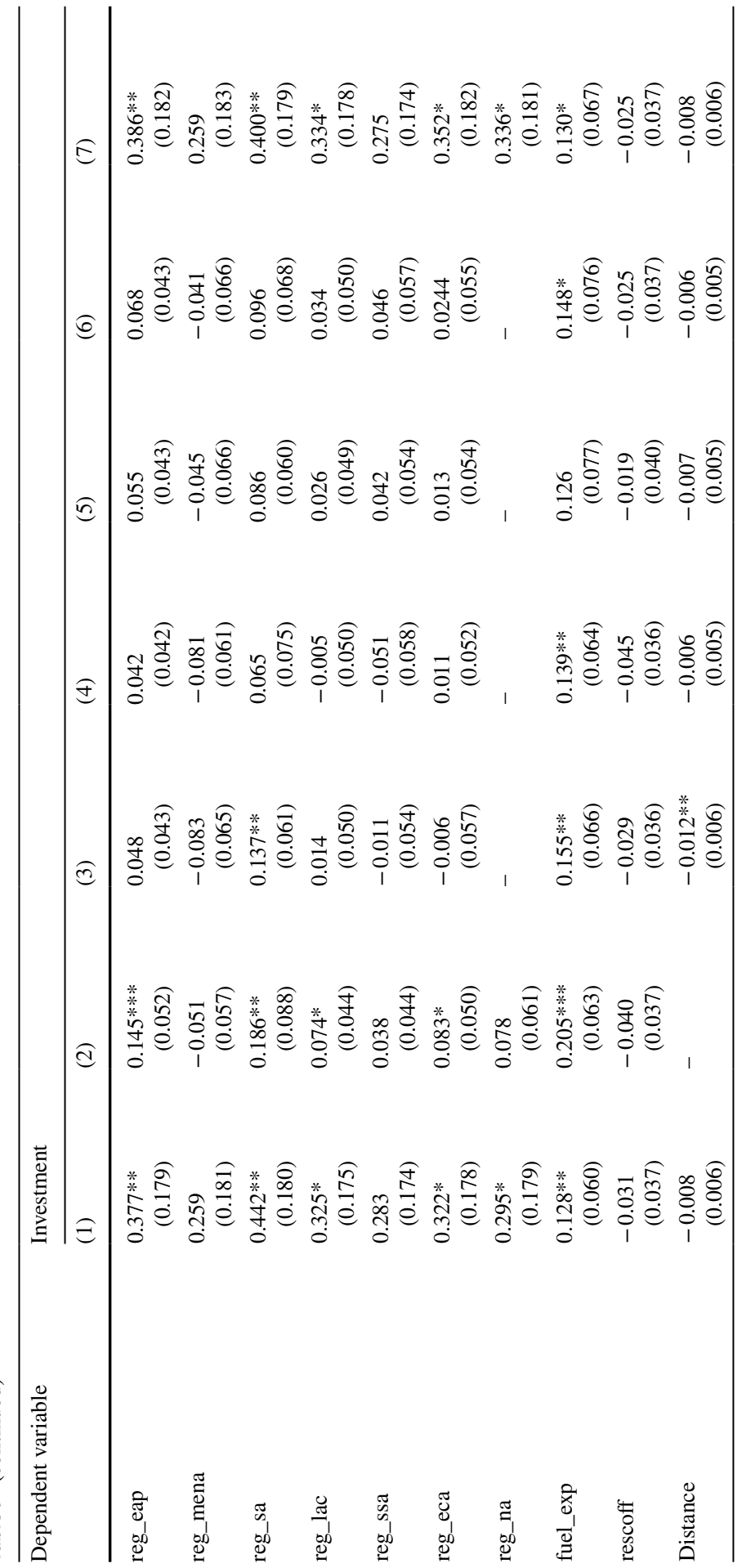




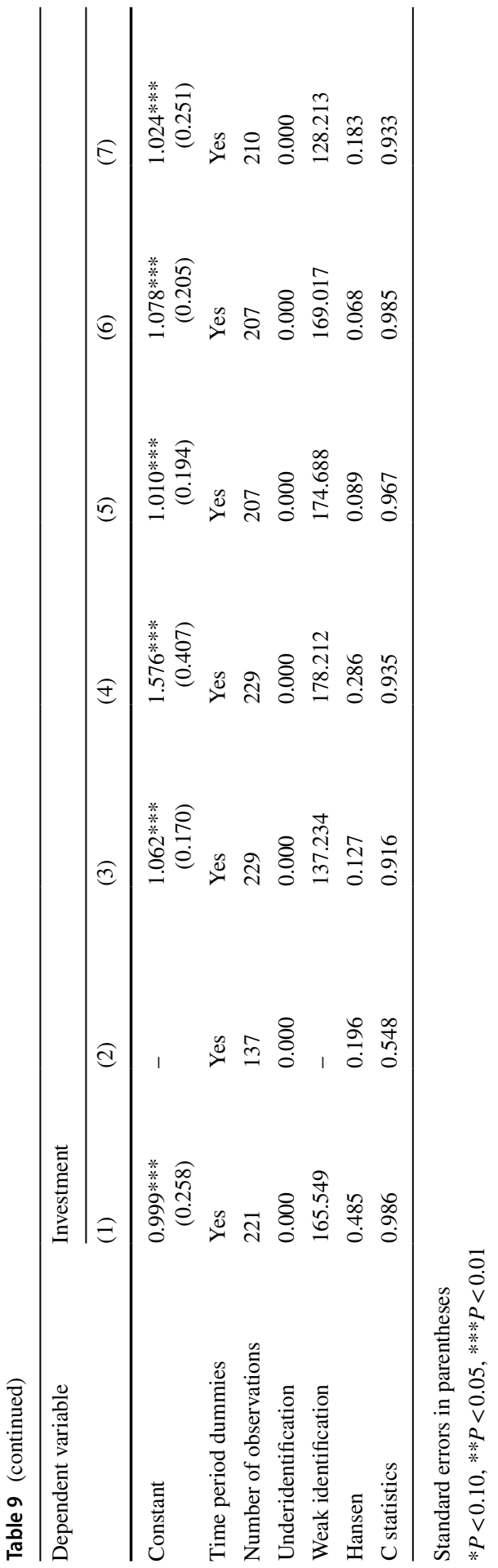


Funding This work was supported by Croatian Science Foundation under the project [IP-2016-06-4682].

\section{Compliance with ethical standards}

Conflict of interest Author Bruno Ćorić declares that he has no conflict of interest. Author Vladimir Šimić declares that he has no conflict of interest.

Ethical approval This article does not contain any studies with human participants or animals performed by any of the authors.

\section{References}

Aizenman J, Marion N (1999) Volatility and investment: interpreting evidence from developing countries. Economica 66:157-179

Almeida H, Campello M, Galavao A (2010) Measurement errors in investment equations. Rev Financ Stud 23(9):3279-3328

Alves J (2019) The impact of tax structure on investment: an empirical assessment for OECD countries. Public Sector Econ 43(3):291-309

Bachmann R, Steffen E, Sims ER (2013) Uncertainty and economic activity: evidence from business survey data. Am Econ J Macroecon 5:217-249

Badinger H (2010) Output volatility and economic growth. Econ Lett 106(1):15-18

Barlevy G (2004) The cost of business cycles under endogenous growth. Am Econ Rev 94(4):964-990

Barro RJ (2006) Rare disasters and assets markets in the twentieth century. Q J Econ 121(3):823-866

Barro RJ (2009) Rare disasters, asset prices, and welfare costs. Am Econ Rev 99(1):243-264

Barro RJ, Jin T (2018) Rare events and long-run risks. NBER Working Paper No. 21871

Barro RJ, Lee JW (2013) A new data set of educational attainment in the world, 1950-2010. J Dev Econ 104:184-198

Barro RJ, Liao YG (2016) Option-pricing formula with disaster risk. NBER Working Paper No. 21888

Barro RJ, Ursúa JF (2008) Macroeconomic crises since 1870. Brook Pap Econ Account 1:255-335

Barro RJ, Ursúa JF (2012) Rare macroeconomic disasters. Annu Rev Econ 4(1):83-109

Baum C, Lewbel A (2020) Advice on using heteroscedasticity based identification. Stata J, forthcoming

Baum C, Schaffer M, Stillman S (2007) Enhanced routines for instrumental variables/GMM estimation and testing. Stata J 7:465-506

Bazzi S, Clemens MA (2013) Blunt instruments: avoiding common pitfalls in identifying the causes of economic growth. Am Econ J Macroecon 5:152-186

Bernanke BS (1983) Irreversibility, uncertainty, and cyclical investment. Q J Econ 98:85-106

Bloom N (2009) The impact of uncertainty shocks. Econometrica 77(3):623-685

Bloom N (2014) Fluctuations in uncertainty. J Econ Perspec 28(2):153-176

Bloom N, Bond S, Van Reenen J (2007) Uncertainty and investment dynamics. Rev Econ Stud 74:391-415

Blundell R, Bond S (1998) Initial conditions and moment restrictions in dynamic panel data models. J Econ 87(1):115-143

Bond SR, Malik A (2009) Natural resources, export structure and investment. Oxford Econ Pap 61:675-702

Buchholz M, Tonzer L, Berner J (2016) Asymmetric investment responses to firm-specific uncertainty. IWH Discussion Papers

Caballero RJ (1999) Aggregate investment. In: Taylor JB, Woodford M (eds) Handbook of macroeconomics, vol 1B. Elsevier North-Holland, Amsterdam, pp 13-862

Candelon B, Carare A, Miao K (2016) Revisiting the new normal hypothesis. J Int Money Financ 66(C):5-31

Candelon B, Carare A, Hasse JB, Lu J (2020) The post-crises output growth effects in a globalized economy. Int Econ 161(C):139-158

Carruth A, Dickerson A, Henley A (2000) What do we know about investment under uncertainty? J Econ Surv 14(2):119-154 
Chirinko RS (2008) $\sigma$ : the long and short of it. J Macroecon 30:671-686

Christiano L, Eichenbaum M, Evans C (2005) Nominal rigidities and the dynamic effects of a shock to monetary policy. J Polit Econ 113:1-45

Ćorić B (2020) Economic disasters: a new dataset. Finance Res Lett. https://doi.org/10.1016/j. frl.2020.101612

Dearmon J, Grier R (2011) Trust and the accumulation of physical and human capital. Eur J Polit Econ 27:507-519

Eberly JC, Rebelo ST, Vincent N (2012) What explains the lagged-investment effect? J Monet Econ 59(4):370-380

Eggertsson GB, Mehrotra NR, Robbins JA (2019) A model of secular stagnation: theory and quantitative evaluation. Am Econ J Macroecon 11(1):1-48

Epaulard A, Pommerte A (2003) Recursive utility, endogenous growth, and the welfare cost of volatility. Rev Econ Dynam 6(2):672-684

Epstein LG, Zin SE (1989) Substitution, risk aversion, and the temporal behavior of consumption and asset returns: a theoretical framework. Econometrica 57(4):937-969

Farhi E, Gabaix X (2016) Rare disasters and exchange rates. Q J Econ 131(1):1-52

Fatas A (2002) The effects of business cycles on growth. In: Loayza N, Soto R (eds) Economic growth: sources, trends and cycles. Central Bank of Chile, Santiago, pp 191-220

Fatica S (2018) Business capital accumulation and the user cost: is there a heterogeneity bias? J Macroecon 56:15-34

Fiori G (2012) Lumpiness, capital adjustment costs and investment dynamics. J Monet Econ 59(4):381-392

Gabaix X (2012) Variable rare disasters: an exactly solved framework for ten puzzles in macro-finance. Q J Econ 127(2):645-700

Gandelman N, Hernandez-Murillo R (2015) Risk aversion at the country level. Fed Reserve Bank SL 97(1):53-66

Glover B, Levine O (2015) Uncertainty, investment, and managerial incentives. J Monet Econ 69:121-137

Gourio F (2012) Disaster risk and business cycles. Am Econ Rev 102(6):2734-2766

Gourio F (2013) Credit risk and disaster risk. Am Econ J-Macroecon 5(3):1-34

Gygli S, Haelg F, Potrafke N, Sturm JE (2019) The KOF globalisation index-revisited. Rev Int Organ 14(3):543-574

Hall RE, Jorgenson DW (1967) Tax policy and investment behavior. Am Econ Rev 57(3):391-414

Isham J, Woolcock M, Pritchett L, Busby G (2005) The varieties of resource experience: natural resource export structures and the political economy of economic growth. World Bank Econ Rev 19(2):1414-1474

Isore M, Szczerbowicz U (2017) Disaster risk and preference shift in a new Keynesian model. J Econ Dyn Control 79(C):97-125

Jones LE, Manuelli RE, Siu HE, Stacchetti E (2005) Fluctuations in convex models of endogenous growth, I: growth effects. Rev Econ Dynam 8(4):780-804

King R, Rebelo S (1993) Transitional dynamics and economic growth in the neoclassical model. Am Econ Rev 83(4):908-931

Kleibergen F, Paap R (2006) Generalized reduced rank tests using the singular-value decomposition. J Econometrics 133:97-126

Kose AM, Prasad ES, Terrones ME (2006) How do trade and financial integration affect the relationship between growth and volatility? J Int Econ 69:176-202

Krebs T (2003) Growth and welfare effects of business cycles in economies with idiosyncratic human capital risk. Rev Econ Dynam 6:846-868

Lane PR, Milesi-Ferretti GM (2007) The external wealth of nations mark II. J Int Econ 73:223-250

Lewbel A (2012) Using heteroscedasticity to identify and estimate mismeasured and endogenous regressor models. J Bus Econ Stat 30:67-80

Lucas R (1987) Models of business cycles. Basil Blackwell, Oxford

Martin P, Rogers CA (2000) Long-run growth and short-term economic instability. Eur Econ Rev 44(2):359-381

Mehra R, Prescott E (1985) The equity premium puzzle. J Monet Econ 15(2):145-161

Meinen P, Roehe O (2017) On measuring uncertainty and its impact on investment: cross-country evidence from the euro area. Eur Econ Rev 92(C):161-179

Ndikumana L (2005) Financial development, financial structure, and domestic investment: international evidence. J Int Money Financ 24:651-673 
Obstfeld M (1994) Risk-taking, global diversification and growth. Am Econ Rev 84(5):1310-1329

Panousi V, Papanikolaou D (2012) Investment, idiosyncratic risk, and ownership. J Financ 67:1113-1148

Pesaran HM (2015) Testing weak cross-sectional dependence in large panels. Econom Rev 34(6-10):1089-1117

Pindyck RS (1991) Irreversibility, uncertainty, and investment. J Econ Lit 29(3):1110-1148

Pindyck RS, Wang N (2013) The economic policy consequences of catastrophes. Am Econ J Econ Polic 5(4):306-339

Priesmeir C, Stahler N (2011) Long dark shadows or innovative spirits? The effects of (smoothing) business cycles on economic growth: a survey of the literature. J Econ Surv 25(5):898-912

Rafferty M (2005) The effects of expected and unexpected volatility on long-run growth: evidence from 18 developed economies. South Econ J 71(3):582-591

Ramey G, Ramey VA (1995) Cross-country evidence on the link between volatility and growth. Am Econ Rev 85(5):1138-1151

Rebelo S, WangN, Yang J (2018) Rare disaster, financial development and sovereign debt. NBER Working Paper No. 25031

Rietz TA (1988) The equity risk premium: a solution. J Monet Econ 22(1):117-131

Roodman D (2009) A note on the theme of too many instruments. Oxford B Econ Stat 71(1):135-158

Seo SB, Wachter JA (2019) Option prices in a model with stochastic disaster risk. Manag Sci 65(8):3449-3469

Stadler GW (1990) Business cycle models with endogenous technology. Am Econ Rev 80(4):763-778

Stock J, Yogo M (2005) Testing for weak instruments in linear IV regression. In: Andrews D, Stock J (eds) Identification and inference for econometric models: essays in honor of Thomas Rothenberg. Cambridge University Press, Cambridge, pp 80-108

Tsai J, Wachter JA (2015) Disaster risk and its implications for asset pricing. Annu Rev Financ Econ $7(1): 219-252$

Wachter JA (2013) Can time-varying risk of rare disasters explain aggregate stock market volatility. J Financ 68(3):987-1035

Wang P, Wen Y (2011) Volatility, growth, and welfare. J Econ Dyn Control 35(10):1696-1709

Weil P (1990) Nonexpected utility in macroeconomics. Q J Econ 105(1):29-42

Publisher's Note Springer Nature remains neutral with regard to jurisdictional claims in published maps and institutional affiliations. 